\title{
RISK MANAGEMENT FRAMEWORK FOR BUILD, OPERATE AND TRANSFER (BOT) PROJECTS IN KUWAIT
}

\author{
Khalid Fahad AL-AZEMI ${ }^{\mathrm{a}}$, Ran BHAMRA ${ }^{\mathrm{a}}$, Ahmed F. M. SALMAN ${ }^{\mathrm{b}}$ \\ ${ }^{a}$ Wolfson School of Mechanical and Manufacturing Engineering, Loughborough University, \\ Loughborough, LE11 3TU, UK \\ ${ }^{b}$ Construction Engineering Department, College of Engineering, Dammam University, Dammam, KSA
}

Received 25 Oct 2011; accepted 10 Jul 2012

\begin{abstract}
Successful implementation of build-operate-transfer (BOT), infrastructure projects is dependent on a full and thorough analysis of factors that include social, economic and political, amongst others. Alongside the financially focused evaluations, qualitative factors will also have a strong impact on the project and so require specific techniques for the analysis. This paper presents a new evaluation framework, based on the analytical hierarchy process technique, for use in assessing the most common and significant decision factors relating to risks in BOT projects. Consultations with an expert group identified a series of risk decision factors. The results produced twenty-eight critical Risk Factors, which have a particular impact on the risks of BOT projects. The project risk framework was constructed by classifying the factors into five categories. The framework was successfully validated using a BOT project case study. This research seeks to make a valuable contribution to the field by having developed and validated a new risk evaluation framework, focused on BOT projects in Kuwait.
\end{abstract}

Keywords: build/operate/transfer (BOT), construction management, risk analysis, risk management framework.

Reference to this paper should be made as follows: Al-Azemi, K. F.; Bhamra, R.; Salman, A. F. M. 2014. Risk management framework for build, operate and transfer (BOT) projects in Kuwait, Journal of Civil Engineering and Management 20(3): 415-433. http://dx.doi.org/10.3846/13923730.2013.802706

\section{Introduction}

The worldwide need for development projects is increasing continuously, particularly regarding all forms of infrastructure facilities. An imbalance in the infrastructure projects and the ability of countries to meet their development requirements has been caused by population growth and the immense, rapid expansion of global economics. The movement towards privatization, both in developed and developing countries has resulted in the participation of the private sector in the improvement of the infrastructure process as a more popular option. This gradually led to the demise of the monopoly held by the public sector, regarding basic infrastructure facilities.

As a result of the reduction in public funding, governments are becoming increasingly dependent on the private sector for the improvement and development of infrastructure projects. This is due to the fact that the private sector is often better equipped in the following ways: the mobilization of resources; the provision of technical and managerial expertise; an improved operating efficiency; the potential for large-scale injection of capital; a greater efficiency in using the capital; utilization of rationalization/cost-base tariffs for services; and a better understanding of customer needs.
Due to the number of parties involved and the corresponding amount of interlocking contracts required, BOT projects are indisputably complex. In this type of project, each party has to rely on the performance of its counterpart, and is also dependent on the lead time of each stage of the project, which can be lengthy. Furthermore, there are high associated upfront costs. There are also a number of complex issues, i.e. government stability, which have to be resolved, specifically with respect to developing countries.

As a result of large capital outlays and the long timescales required to generate returns for investors, BOT infrastructure projects carry an inherent risk. There is an increased probability of problems arising when such long timescales are involved. The relative amount of loss could potentially be huge, given the very large capital outlays required. Therefore, the decision to invest in BOT projects is affected, to a large extent, by the perception of risk.

The purpose behind the Kuwaiti governments program of privatization is essentially to ease the financial burden on the public by reducing the costs connected with public debt. It also assists in the transition of the central economy from a planned to a free market and in many cases results in an improvement in public services. 
It involves a partnership between the public and private sectors, which is essentially a service contract in which the private sector plans the funding of the project and provides the assets required to deliver it, while the public sector selects and purchases the necessary services it provides a suitable opportunity to provide high-quality services which are fully equipped and well insulated, using private sector funding, with the risk factors passing from the public to the private sector and avoids the need of the public sector to purchase capital assets.

In order to study the impact on the economy of the general privatization process, it is possible to measure the percentage increase in the amount of private sector participation within the economy, the improvement in the trade balance, the growth in the domestic capital markets, decrease in the budget deficit, reduction in unemployment levels, as well as the financial, quality of service and profitability indicators.

The Sulaibiya Waste Water Treatment contract in Kuwait, signed in May 2001, was commissioned in 2004 and currently processes 50 million gallons of water per day for irrigation purposes. It is the largest BOT project to date and revenues were projected of USD 390 million over 10 years. Privately owned Kuwaiti companies have launched projects in real estate and one of these, the Kuwaiti National Real Estate Company completed the USD 132 million Sharq Mall in 1998. In 2002 the Marina Mall, a USD 162 million BOT, was completed by the Kuwaiti United Realty Company. More recently, in February 2010, the Kuwaiti Government approved a major development plan consisting of 1,100 projects totalling KD 30.8 (USD 107.8 billion). The projects include a free trade zone with 700,000 residents, a planned financial and commercial hub and the creation of a Silk City program all of which, according to the Minister of State for Housing and Development Affairs, are intended to be undertaken as BOT projects.

There are several disadvantages to the privatization process, which include a lack of expertise, insufficient legislative cover, a lack of regulations covering the relationship between the participating parties, which would protect their rights and ensure compliance with the details of the contract. The State authorities expended a great deal of effort in order to achieve satisfactory results.

However, while bidding for BOT projects, some investors submitted high offers, without realistically considering the risks and opportunities involved. Also, many of the methods were not transparent as the main concern of investors was to earn extra profit and guarantee beneficial financial results. As a result, legal and contractual issues have been raised, with a negative effect on the projects and a lack of confidence and increasing tension between the parties involved in the contract. The experience gained has had advantages as well as disadvantages, but the problems have been emphasized for political reasons, so it was necessary for the government to pay special attention to Build-Operate-Transfer (BOT). This indicates the serious intention of the government to implement privatization policy and to involve the private sector in the execution and development of projects and services.
Some articles within the legislation may have prevented investors from participating in certain projects and public opinion is also an important factor to consider. These issues have resulted from the new BOT law and also the economic boom, which occurred during the recovery period over the last five years. Even though only three years have passed since the enactment of the law and decree, critics are still requesting amendments to the law. This in fact occurred even before there was an awareness of the unknown risks involved. The crisis of confidence between the public and private sectors is still in existence and so the causes need to be addressed so that all parties will benefit from the legislation and so that it can lead to successful projects resulting in improved development for the whole country.

Unfortunately, due to the extended process of procurement in Kuwait, many accusations of attempted bribery and inducements have been leveled at bidders. Several investigations and trials are currently in process, which involve accusations against current or previous government officials. Since the end of the Gulf War, however, there have been no convictions for bribery

Law No. 25 was passed in 1996, in which all companies securing contracts worth KD 100,000 (USD 364,931) or more must report all payments made to Kuwaiti agents or advisors during the time of securing the contract. In the same way, individuals in Kuwait should report any compensation payments received when securing government contracts.

In 2010, Transparency International's Corruption Perceptions Index (CPI) discovered Kuwait to be $54^{\text {th }}$ out of 180 countries. Within the Arab region, it was ranked seventh out of 18 countries. According to Transparency International, Kuwait's CPI score of 4.5 (out of 10) indicates that it suffers from a "serious corruption problem".

According to the World Bank (1994), it is widely accepted by virtually all governments that one of the most important factors in encouraging national economic growth is having an appropriate and reliable infrastructure. Even though economists find it hard to agree about the elasticity of infrastructure investment, studies have shown that infrastructure is extremely important to successful economic activity.

However, it is often the case that governments in countries with developing economies rarely have the financial resources needed either to create new, or maintain current, infrastructure facilities. Unfortunately, inefficiency and a lack of openness in management dealings and decisions, has resulted in a low standard of service to the community development for the whole country.

It is inevitable that risks are a crucial part of BOT projects. These risks are quite complicated because of the high levels of investment, the length and complex nature of the project setup, which is required when all of these risks are combined. The companies involved in the BOT projects assume responsibility for a wide range of risks throughout the life-cycle of the project, while the private sector assumes responsibility for the finance, design, construction and operating risks. This paper examines and discusses the risks faced in BOT projects in the State 
of Kuwait, prioritizing them, and suggesting a framework to manage the risks in the Kuwaiti environment.

\section{Background}

The previous tradition, in which government funds infrastructure developments, has been changing Shen et al. (2007). More recently, private businesses have been given opportunities for involvement in the funding and development of infrastructure. The reason for this is that private businesses have access to large amounts of capital and often have greater management expertise than the government. The lack of financial resources is particularly relevant in developing countries, Shen et al. (2007).

According to Shen et al. (2002), the build-operatetransfer (BOT), contractual arrangement enables governments to build more infrastructure services by using private finance and management skills, rather than public funds. The BOT concept has contributed to the development of infrastructure works worldwide, most noticeably in developing countries, Shen et al. (2007). This method mobilizes private funds and also utilizes the available new technology, management skills, and operational efficiencies which private businesses are able to provide in the development of infrastructure Shen et al. (2007). In Southeast Asia, in particular, according to Shen et al. (1996), governments have been increasingly using BOT methods to build railways, highways, tunnels, ports, bridges, reservoirs, power plants and hydraulic facilities.

According to Levy (1996), the first BOT contract project in modern times dates back to the building of the Suez Canal, built in 1854. For this project, the company, Compagnie Universelle du Canal Maritime de Suez, received a concession from the Egyptian government lasting for 99 years, enabling it to construct and operate a canal which connected the Mediterranean Sea to the Red Seas. However, as noted by Huang (1995), the method was still rarely used until the mid-1980's but since then the use of the BOT method has increased considerably, making a significant contribution to the development of worldwide infrastructure.

Delmon (2000) carried out a study in which he found that there are significant risks involved in achieving the objectives for a BOT project and they come from various sources, such as: the economic environment, the capital budget, the construction cost and time, the operational costs, as well as the politics and policies prevalent at the time. Current market conditions and cooperation credibility also play an important role. Both the private sector and the government therefore need to pay particular attention to the effect of these risks before becoming involved in a BOT contract.

A hydropower plant project in Turkey was considered by (Ozdoganm, Birgonul 2000), in order to discover the viability of qualitative decision factors, using a checklist approach. To achieve this, they used three criteria, which were government actions (Gas), country specific (CS) and project specific (PS). As these were quite subjective criteria, it was impossible to discover the precise influence of the qualitative decision factors on the feasibility of the project. Using their checklist approach could result in the neglect of possible strategies which might have improved certain qualitative aspects of a project decision.

A desirability model, which measures the competitiveness of a company and the attractiveness of a project, from a private promoter's point of view, was provided by Dias, Ioannou (1995b), who analyzed a set of country and project decision factors and produced a project attractiveness index. However, the difficulty with the application of this method, in practice, is that it would take quite a large amount of time and increase the cost of a project feasibility study. It might also result in the misinterpretation of project decision factors and some of them might actually be missed. In the desirability model, the attribute worth score was only valid when the attribute performance was between two extreme values $P 1$ and $P 2$. Where, $\mathrm{P} 1$ is the minimum plausible performance level for an attribute and would indicate the highest point on the performance scale where an attribute is worth its minimum (i.e. 0 worth points). The maximum plausible performance level, $P 2$, indicates the lowest point on the performance scale and occurs where an attribute value is at its maximum (i.e. 100 worth points).

The different variables, which affect the concession period of a BOT contract, were reviewed by Shen et al. (2002), who suggested that, in order to determine a suitable time period for the project, taking into account both the government's and the investor's interests, a quantitative concession model (BOTCcM), should be considered. Shen et al. (2005), in their investigations discovered that the risks involved in the implementation of a BOT project, had a marked effect on the cash flow for the project. Using Monte Carlo simulations, they incorporated project risks into the BOTCcM. However, in a BOTCcM, all BOT factors other than the concession period are predetermined, so it does not allow for different combinations of the concession period with other BOT financial variables.

\subsection{Nature of infrastructure projects}

Recently, the attention given to urban regeneration projects has significantly increased. Such initiatives use redevelopment projects to resolve the social and economic problems caused by antiquated buildings and degraded infrastructure, Kim (2010). However, common infrastructure projects such as power, water and sewerage, telecommunications and transport facilities possess a number of characteristics: they lack portability, are rarely convertible to other uses and it can be difficult to reverse any investment made in them. The majority of infrastructure projects require large investment capital, are single-asset investments and developed over a long period of time; they also have long periods of payback. However, they do provide important services, which would usually fall to the public sector and they generally operate as monopolies. The nature of infrastructure projects makes them responsive to public opinion and political pressure. Contrary to other types of foreign direct investment, most infrastructure projects only generate local currency, but the dividends and loan repayments are paid in foreign 
currency. The process of building infrastructure facilities is also complex and very risky.

\section{Definition of BOT approach}

BOT is a term used for the financial involvement of the private sector in various infrastructure projects. BOT should not be thought of as a legal term, but rather as an economic and financial concept. As defined by Tiong (1995a), it is "the granting of a concession by the Government to a private promoter, known as the concessionaire, who is responsible for financing, construction, operation and maintenance of a facility over the concession period before finally transferring the fully operational facility to the Government at no cost".

There are several different definitions of BOT:

- Tiong (1995c) states that it is a method of project financing in which a government awards a concession to a group of investors, known as the "Project Consortium" for the development, operation, management, and commercial exploitation of a particular project;

- According to Esq (1996), BOT is a method of financing a project in which the government grants a concession to a private entity or project company to build and operate a project, which would usually be operated by the government itself;

- Nassar (1996) defines BOT as the involvement of Concession Company which provides the finance for, and then designs, constructs, operates, and maintains a particular infrastructure project for a pre-defined length of time, after which it is transferred back to the host government without any charge.

In any BOT scheme the concession company finances, designs, constructs, operates and maintains a particular facility for a fixed period of time, which should be long enough to pay off all debts and provide a reasonable profit to the equity investors. At the end of the specified time, the facility passes, without charge, to the public authority or the government (Walker, Smith 1995; Wilburn, Thomas 1994). The BOT model is a method in which a group of private investors form a consortium to complete an infrastructure project including its design, finance and construction. It then operates the project for a period of time on behalf of the promoter (which may be the government). This is known as a franchise/concession and involves the building and operation of the project for a length of time before it is passed back to the host authority (Shen et al. 2002; Askar, Gab-Allah 2002).

\subsection{Risk in BOT projects}

One of the main methods for procuring and delivering public infrastructure projects is the public-private partnership (PPP), and, according to Regan et al. (2009), it has been used in over 85 countries. Its specific features include improved public facilities and services, a competitive bidding process, and a suitable balance of project risks, together with the innovation and expertise of the private sector.

The National Council for Public-Private Partnerships, USA (2009), have defined a public-private partnership as "a contractual agreement between a public agency - federal, state, or local - and a private sector entity", in which a sharing of the assets and skills of each sector results in the provision of a public service or facility for the use of the general public. According to $\mathrm{Li}$ et al. (2005), it is considered to deliver value for money in the provision of public services and infrastructure by combining the advantages of flexible negotiation and competitive tendering and by allocating risk, on an agreed basis, between the public and private sectors.

According to Kumaraswamy, Morris (2002), BOT schemes may be either private participation (PP), or public-private partnerships (PPPs). Other collective terms are: build and transfer (BT), build, transfer, and operate (BTO), build, operate and own (BOO), build, operate, own, and transfer (BOOT), operate and transfer (OT), reconstruct, operate, and transfer (ROT), etc. all of which are subject to concession agreements. As Tiong (1995a) states, a BOT infrastructure project may be implemented by a government grant, with a concession company which will finance, construct, operate and maintain the project before transferring ownership back to the government after an agreed concession period. Senturk et al. (2004), note that BOT schemes, as adopted in many industrialized countries, use private sector participation to finance new infrastructure projects. A number of studies (Tiong 1990; Dias, Ioannou 1995b; Liddle 1997) show that government-sponsored BOT schemes encourage the participation of the private sector in large public infrastructure projects such as roads, expressways, bridges, railways, ports and power plants, which are built and/or operated by private firms under a procurement system. However, there is much risk attached to the process and this must be carefully evaluated by both the private bidders and the public client, throughout the whole duration of the project. An effective management framework needs to be set up to deal with the risk on a theoretical and practical basis.

There is risk involved throughout the life of the project and, as BOT-type projects require large investments and cover long time periods, as Shen et al. (2005) state, during the concession period, these many risks and uncertainties could potentially affect the performance of the project.

The BOT projects undertaken by the private sector contain many risks and uncertainties (Songer et al. 1997). The BOT projects are generally large-scale projects providing infrastructure facilities and the transaction costs on average are between 5 and $10 \%$ of the overall project cost (Klein et al. 1996).

Projects involving the building of infrastructure have a higher risk element because the capital costs are usually high, there is often a long lead-time and the resulting assets do not usually have any alternative use. It is very important, therefore, to identify, analyze and allocate the different risks when evaluating privately promoted infrastructure projects. The risks involved in BOT pro- 
jects are two-fold. First, there are the risks involved in the start-up procedure (financial and technical studies) and also finance and operational risks due to the nature of the BOT approach; and secondly, being large-scale projects, there are also regulatory, political and economic risks involved (Ebrahimnejad et al. 2010).

According to Tiong, Alum (1997) due to the high level of risk associated with BOT projects, the negotiators and Decision Makers (DMs), for both the public and private sectors need to carry out a careful analysis and then manage these risks. However, as pointed out by Ozdogann, Birgonul (2000) the private sector and the government do not share a set of principles covering the risks associated with BOT projects, and so, according to Tiong (1995c), the promoter who wins the concession is more likely to be the one who carries the risk and offers suitable guarantees. According to Gunn (2005), risks and ambiguity will be present in all construction projects and tend to involve the three main project management restrictions of time, quality and budget. The many risks involved in construction are considerably increased in BOT projects, due to the complex combination of various issues such as design, construction, operation and finance. The risks themselves are more complex than for conventional projects because of the higher number of parties and agreements concerned. The working environment is very different in BOT projects and so both the private and public sectors need a change in attitude towards the risks involved. Governments usually attempt to transfer as much risk as possible to the private sector, while the private sector is asked to assume that risks inherent to the project are assigned to the appropriate party.

Public-Private Partnership (PPP) is a procurement approach where the public and private sector join forces to provide a public service or facility. In this agreement, usually both the public and private sector will contribute their expertise and resources to the project and share the risks involved, (Cheung et al. 2010). The Public-Private Partnership (PPP) projects fall into two main groups, consisting of general and project risks (Loosemore 2007; Loosemore et al. 2006). The risks within a BOT project will change during the development process, and so they will change at each stage, from the planning phase through to the design, construction and operation phases.

There are six areas of risk associated with PPP projects, according to Grimsey and Lewis (2004), and these are: financial, asset, sponsor, operating, public and default risks. The main categories of risk in BOT projects have been identified (Dey et al. 2002) as economic, political, legal, construction, financial and operating risks. According to (Baloi, Price 2003), the risks also need to be categorized as: static/dynamic, individual/corporate, internal/external, positive/negative, acceptable/objectionable and insurable/uninsurable. For this reason, government assurance is extremely important in BOT projects. The more easily observed risks are: economic, political, financial and related risks.

\subsection{Risk management in BOT projects}

Risk management is an "activity that defines sources of uncertainty (risk identification), estimating the consequences of uncertain events/conditions (risk analysis), generating response strategies in the light of expected outcomes and finally, based on the feedback received on actual outcomes and risks emerged, carrying out identification, analysis and response generation steps repetitively throughout the life cycle of an object to ensure that the project objectives are met" (Zavadskas et al. 2010). According to Gunn (2005), the importance of risk management to the success of BOT projects cannot be overestimated. There are many different types of risk and uncertainty involved in every construction project, however small. These may be: technical, economic, legal, etc. but they all ultimately involve an organization in financial risk. The risks pertaining to BOT projects are more complicated than the traditional methods, where the design is separate from the construction and the client is responsible for the project. This is not only due to the long duration, high investment and complicated methods of procurement, but also because all of these risks are combined, with the companies involved in the project assuming responsibility for a whole range of risks within the life-cycle of the project and the private sector taking responsibility for financial, design, construction and operating risks. The three main areas of risk generally center on the project management constraints of time, quality and budget.

Dey and Ogunlana (2004) consider that ineffective risk management is one of the major causes of failure of BOT projects, which are considered to be the most risky project schemes. An understanding of the contents and contexts of BOT projects is extremely important today, as are the risk-management tools and techniques available. The application of these tools will depend on various factors including the policy requirements of the organization, the project management strategy, the nature of the project, the attitude of the project team to risk taking and the availability of resources.

Raz, Michael (2001) commented that risk management has been a main topic of interest for researchers and practitioners who are involved in project management. Flanagan, Norman (1993) have defined risk management as a system which aims to identify and quantify all risks to which a business or project is exposed so that a conscious decision can be taken on how to manage those risks. Risk management acknowledges the possibility that future events may produce negative or adverse effects and employs the design and implementation of systems or procedures which will control these risks. This definition also explains that the purpose of risk management is to manage systems in order to control risks.

Although risk management need not be very complicated or involve data collection on a large scale, it should be cost effective, practical and, of course, realistic. Often, in addition to analysis, judgment and experience, it is based on common sense, intuition and 'gut feeling' but, most of all, there needs to be a willingness to adopt a disciplined approach. Depending on the circumstances involved in each project, there will be different degrees of 
analysis. It is therefore important to formulate a structured risk-analysis system.

Experience shows that, the identification and classification of risks is more difficult than actually controlling them. Decision-makers therefore need to identify the risk and plan a risk-management system, otherwise they will lose control of the system and fail to find solutions to the risk or solve any of the problems within the system.

Ghosh and Jintanapakanont (2004) suggest that risk management is a tool for managing projects effectively throughout their lifecycles.

Due to the uncertain nature of risks, decision makers need to consider which specific risks need to be analyzed and then devise strategies to deal with them. Although risk management will not remove every risk from the project, it is intended to identify them early on so that their relative importance can be assessed and recommendations made on how best to control them in order to provide the best outcome for the project.

\section{Research methodology}

The most important task of risk management is to analyze the risk so that appropriate decisions can be taken. Ahmed et al. (2007), Zayed and Chang (2002) have cited Dias, Ioannou (1995b), as providing a proposal for both a qualitative and quantitative approach to risk analysis. A risk index is derived using the main risk categories within a concession-type agreement. These are then rated using a scaled value. The first stage in this paper is to specify the different variables, (numerical and linguistic), which would affect the project risk. This can be achieved by gathering all the related variables from the database of previous projects and the project environment, (e.g. conditions in the host country, the characteristics of the project and its location). The BOT project risk factors can be selected by evaluating a wide range of risk factors and their sub-factors can be obtained from the literature (Tiong 1990, 1995a, b, 1996; Tiong et al. 1992; Levy 1996; UNIDO 1996; Gupta, Narasimham 1998; Ranasinghe 1999; Ozdoganm, Birgonul 2000). The second stage is to identify the variables and classify them after removing the redundant ones. The risk factors can be grouped within the main categories in order to reduce extensive effort and save time in determining their interrelationships and evaluation. This should be carried out by a group of experts in the field. The third stage is to apply mathematical methods used for processing the data. In this study, the methodology adopted will determine the most common and important risk factors (variables), affecting the risk of BOT infrastructure projects in $\mathrm{Ku}-$ wait and, to then to discover the extent to which they can be controlled. A set of linguistic variables are categorized according to their relevance. The flow chart in Figure 1 demonstrates the methodology used in this study. The absolute of project decision risk analysis is the "risk index" $V(x)$, which assesses the risk of the project. This a non- dimensional risk measure shown in Eqn (1) below:

$$
V(x)=-\sum_{i=1}^{n} w_{i} v_{i}\left(x_{i}\right) .
$$

Dias and Ioannou (1995a) considered the value function as a function used to transform an outcome (i.e. the performance level of an attribute) into the decisionmaker's relative worth for this outcome. Transforming an attribute performance level to its "worth" score, by means of a "value" function, is more complicated than estimating the performance (quality), level of an attribute directly through the use of a quantitative scale. It was very difficult to choose appropriate quantitative constructs to represent the model attributes, so a qualitative scale, common to all attributes, was considered to be the best alternative for the development of the model. The "worth" score of an attribute, $V_{i}\left(x_{i}\right)$, is a non-dimensional number representing the performance level for a specific project. In order to calculate the worth score of an attribute, its performance level must be qualitatively assessed, and then the value function used to transform the subjectivity assessment into a numerical scale.

\section{Questionnaire and expert criteria}

The project risk attributes include a combination of qualitative and quantitative factors and, in order to determine their inter-relationships, it is necessary to assign "weights" to the performance (quality), levels for each attribute contributing to the project risk and to compare their relative importance. To carry out this important process it is necessary to gather the required information from experienced professionals in the industry, who are especially involved in the development of BOT projects. For this research, the selection of the professional group of respondents was based on the following criteria:

- The expert should be involved in developing one of the BOT projects;

- The expert should be one from the top project management team;

-A whole variety of project-type experience must be considered;

- Experts, (public or private agencies or financiers), were selected from diverse project participants to reflect the likely differences in opinions of project participants concerning the risk of potential projects and the degree of importance of differing project attributes.

A BOT project risk framework is an evaluation framework that is multi-attributed and it was developed with information gathered from two self-administered questionnaires, which were distributed with Kuwait. The first questionnaire was designed to assess the common risk factors, found in the literature, which affect the BOT project system. The first questionnaire included 80 factors compiled from previous studies. These were grouped together under the name of the corresponding risk factors. Experts ranked the common BOT risks factors according to their relevance in each of the project categories. These same experts were also asked to add further attributes which they considered necessary to reinforce the quality 


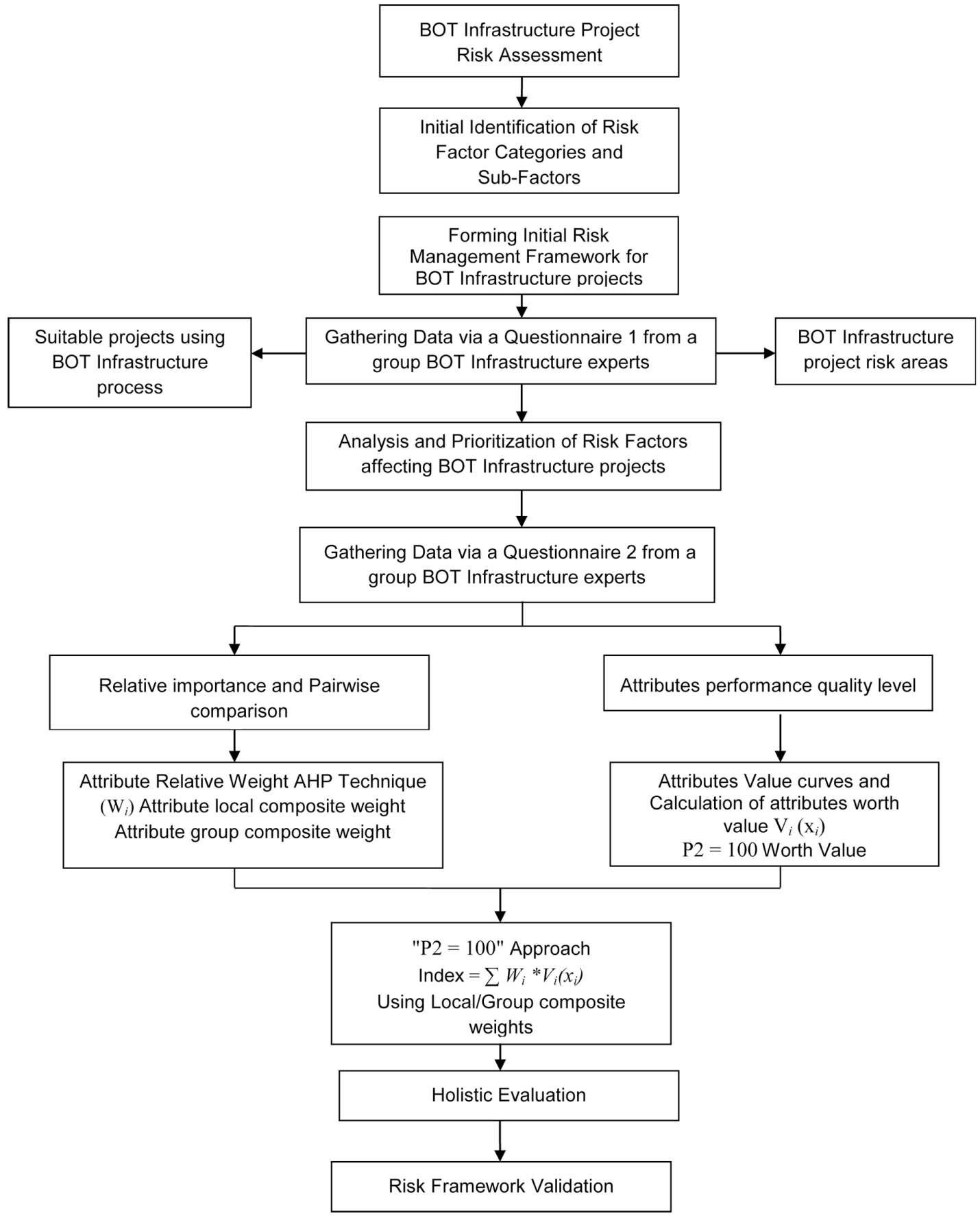

Fig. 1. Study methodology flow chart

of the framework, (although no additional attributes were actually identified in this method). The information gathered from the first questionnaire was refined, compiled and screened by using mean average and standard deviation and it resulted in five Risk Categories with their related twenty-eight Risk Factors which were used to form a hierarchical structure of the framework shown in Figure 2. Included in the second questionnaire was the hierarchical structure of the framework, which was designed to check the relevance of each factor with regard to its corresponding category, to assign a weight and performance level to each risk factor and also to evaluate the case study project holistically. A variety of experts were chosen in order to identify and evaluate the most common attributes, which would have the most significant impact on the BOT project risk. The first questionnaire was sent to sixteen local Kuwaiti BOT experts representing different sectors (financial, legal, consultancy and development, university professors, and official agencies). Their answers represented their understanding of the problem. Five were project company managers involved in only one BOT project, three were project heads of site offices, four were involved in more than one BOT project as engineering consultants, two academic experts were involved in a number of BOT projects as management construction consultants, and two were involved in BOT projects as financial consultants. The second questionnaire survey was sent to fourteen of 
the original sixteen local Kuwait experts (two did not want any further participation in the survey). These fourteen respondents returned fully completed surveys and also had expressed a willingness to offer more support to this study. It is possible that this low sample number could be ascribed to the fact that the respondent criteria called for very qualified experts in BOT systems who had the knowledge and ability to deal with a whole complexity of qualitative decision factors and their relationships. Previous studies have shown that the response rates to requests for qualitative factor assessment has been very low: for example, in Dias and Ioannou (1995b), only twelve and eight respondents had accepted the invitation and completed the questionnaire and in Ahmed et al. (2007), only twelve and fifteen respondents had accepted the invitation and completed the survey. The resulting "inconsistency ratio" of the pairwise comparison matrix was $<0.1$ for answers from every respondent. This represents a further encouraging sign of the reliability of the responses received.

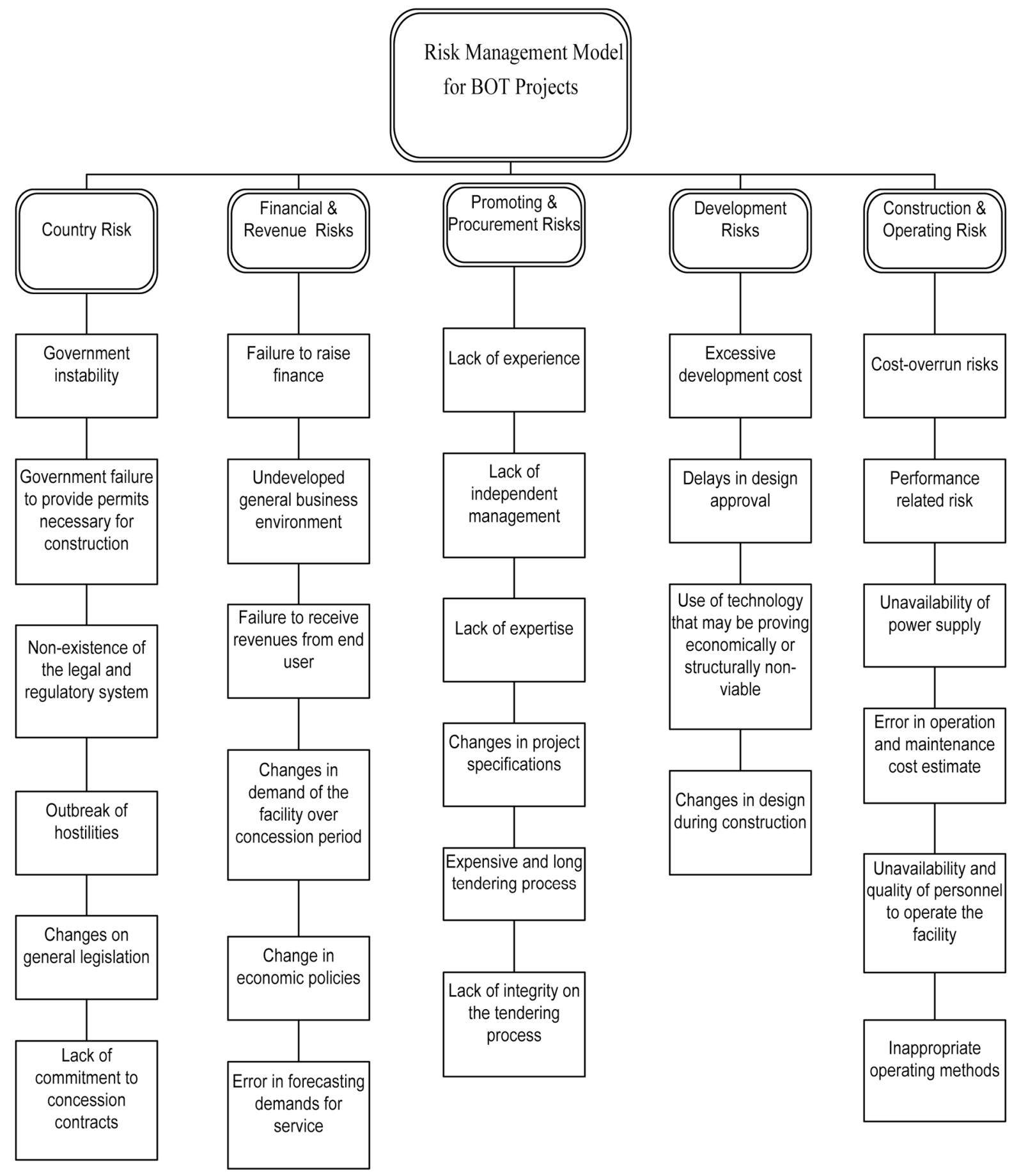

Fig. 2. Hierarchical structure of BOT project risk management framework 
Table 1. Category pairwise comparison matrix and relative weights

\begin{tabular}{lcccccccccccccc}
\hline & $\mathrm{R} 1$ & $\mathrm{R} 2$ & $\mathrm{R} 3$ & $\mathrm{R} 4$ & $\mathrm{R} 5$ & $\mathrm{R} 6$ & $\mathrm{R} 7$ & $\mathrm{R} 8$ & $\mathrm{R} 9$ & $\mathrm{R} 10$ & $\mathrm{R} 11$ & $\mathrm{R} 12$ & $\mathrm{R} 13$ & $\mathrm{R} 14$ \\
\hline $\begin{array}{l}\text { Category Relative } \\
\text { Importance }\end{array}$ & & & & & & & & & & & & \\
$\quad$ CR versus FR & 1 & $1 / 9$ & $1 / 3$ & 6 & 1 & $1 / 3$ & $1 / 2$ & $1 / 3$ & 4 & 5 & 1 & 1 & $1 / 2$ & 2 \\
CR versus PP & 2 & $1 / 7$ & $1 / 4$ & 9 & 3 & $1 / 3$ & $1 / 2$ & $1 / 3$ & 7 & 5 & 3 & 2 & 7 & 5 \\
CR versus DR & 2 & $1 / 6$ & $1 / 5$ & 9 & 1 & $1 / 3$ & 2 & $1 / 3$ & 7 & 5 & 1 & 1 & $1 / 3$ & 7 \\
CR versus Co & 8 & 1 & $1 / 5$ & 9 & 1 & $1 / 5$ & 2 & $1 / 5$ & 9 & 5 & 1 & 9 & $1 / 3$ & 7 \\
FR versus PP & 7 & 3 & $1 / 2$ & 9 & 1 & $1 / 3$ & 6 & $1 / 4$ & 9 & 3 & 1 & 9 & 9 & 7 \\
FR versus DR & 4 & 5 & $1 / 3$ & 9 & $1 / 3$ & $1 / 7$ & 5 & 1 & 9 & 3 & $1 / 2$ & 2 & 3 & 9 \\
FR versus CO & 4 & 5 & $1 / 5$ & 7 & 2 & $1 / 3$ & 3 & $1 / 3$ & 5 & 3 & 3 & 5 & 2 & 7 \\
PP versus DR & $1 / 5$ & 1 & $1 / 6$ & 1 & 1 & 1 & 1 & 1 & 1 & $1 / 3$ & 1 & $1 / 5$ & $1 / 6$ & 2 \\
PP versus CO & 1 & 1 & $1 / 5$ & 1 & 2 & $1 / 3$ & $1 / 2$ & $1 / 3$ & 1 & $1 / 3$ & 1 & $1 / 2$ & $1 / 4$ & $1 / 3$ \\
DR versus CO & 4 & 1 & $1 / 2$ & 1 & 3 & $1 / 2$ & $1 / 2$ & $1 / 5$ & $1 / 3$ & $1 / 2$ & 3 & 5 & $1 / 2$ & $1 / 5$ \\
Weights & & & & & & & & & & & & & \\
CR & 0.30 & 0.05 & 0.05 & 0.61 & 0.25 & 0.06 & 0.17 & 0.06 & 0.55 & 0.53 & 0.24 & 0.28 & 0.13 & 0.44 \\
FR & 0.39 & 0.51 & 0.09 & 0.26 & 0.17 & 0.09 & 0.46 & 0.12 & 0.29 & 0.20 & 0.21 & 0.36 & 0.38 & 0.37 \\
PP & 0.07 & 0.18 & 0.12 & 0.04 & 0.18 & 0.19 & 0.13 & 0.22 & 0.05 & 0.06 & 0.16 & 0.06 & 0.04 & 0.06 \\
DR & 0.18 & 0.15 & 0.32 & 0.04 & 0.29 & 0.27 & 0.09 & 0.14 & 0.04 & 0.09 & 0.27 & 0.24 & 0.20 & 0.03 \\
CO & 0.06 & 0.11 & 0.43 & 0.04 & 0.12 & 0.38 & 0.15 & 0.46 & 0.07 & 0.12 & 0.13 & 0.06 & 0.25 & 0.10 \\
\hline
\end{tabular}

\subsection{BOT risk model attributes selection}

The first questionnaire assessed the common risk factors, which affected the management systems for BOT infrastructure projects and also ranked the common BOT risk factors according to their relevance to each of the project categories on a qualitative scale of one to nine points.

After careful selection of the project risk factor model attributes, 28 attributes were extracted from the first questionnaire. The attributes were identified and classified under five main risk categories. In order to reduce the size of the comparison matrix and also to ensure that the comparison attributes were more meaningful, only attributes of the same nature were compared and these were divided into five categories. This was following the assumption made by Miller (1956), that the brain could simultaneously process $7 \pm 2$ items.

\subsection{BOT project risk attributes relative weights}

From the responses obtained, pairwise comparison matrices of the project risk model were constructed, which represented their relative importance, based on a numerical scale of 1-9. By means of the Eigenvalue Method (EM) in the Analytical Hierarchy Process (AHP) the categories and their local weight attributes were calculated using the computer software package "Expert Choice 11 " which is a computer application of the AHP technique. The input data included the formatted risk framework categories and attributes as a hierarchical structure with all the given relationships shown, as well as the pairwise comparison matrix values for each participant. Expert Choice 11 was used to find the inconsistency ratio of each matrix. For each respondent, the software output shows the inconsistency ratio for each comparison matrix and the local importance weight for each decision factor (alternative), within the category (objective), and the importance of the composite weight of each factor to the total project risk (goal).

\subsection{Category weights}

The project risk attributes were classified within five main categories as shown in Figure 2. The individual results provided by participants, for comparison of the relative importance of the different categories, and the calculated category weights, are presented in Table 1 .

The results indicate that $35.7 \%$ of the responses suggested that the "Financial \& Revenue" risk category is the most important one (superior), within the project risk decision, while $28.5 \%$ find the "Country Risks" category to be the most important, ranking it second in the list. A further $21.5 \%$ thought that "Construction \& Operating" risk was the most important category, while $14.3 \%$ found "Development Risk" to be the most important category. "Promoting \& Procurement" risks came out as the least important of all. Taking average weights for the five categories, indicates that "Financial \& Revenue" risks carry $28 \%$ of the total project risk, while "Country Risks" follow closely with $27 \%$, "Construction \& Operating" risk carries 18\%, "Development Risk" has 17\% and "Promoting \& Procurement" risk has $10 \%$ of the total.

From this it can be concluded that the "Financial \& Revenue" risks category is the most important, being slightly ahead of the "Country Risks" category and about twice as significant as the "Construction \& Operating" risk and "Development Risk" categories. It thus follows that the decision-maker needs to give the highest priority to "Financial \& Revenue" risks and "Country Risk" factors when carrying out an assessment for project risks in Kuwait.

In order to calculate the contribution weight of each category to the total project risk, the overall weight of individual responses (the group weight) for each category is required. A geometrical, rather than the arithmetic, mean of responses was used to group the individual judgments for each category, because, according to Saaty and Aczel (1983), the method used to consolidate individual judgments, needs to preserve the reciprocal nature of 
the comparison matrix. From Table 2 it can be seen that the group weights of categories are approximately similar to the average of the local weight. It is apparent that the "Financial \& Revenue" risks category has the highest weight of $31.1 \%$, followed by "Country" risks, which have $23.4 \%$ and the "Promoting \& Procurement" risks category, which has the lowest weight of about $10 \%$.

Table 2. Category group pairwise comparison and group relative weights

\begin{tabular}{|c|c|}
\hline Category Comparison & $\begin{array}{l}\text { Relative Importance } \\
\text { (Geo-mean) }\end{array}$ \\
\hline $\begin{array}{l}\text { Country Risk (Political \& Regulatory) vs } \\
\text { Financial \& Revenue Risks }\end{array}$ & 0.90 \\
\hline $\begin{array}{l}\text { Country Risk (Political \& Regulatory) vs } \\
\text { Promoting \& Procurement Risks }\end{array}$ & 1.61 \\
\hline $\begin{array}{l}\text { Country Risk (Political \& Regulatory) vs } \\
\text { Development Risk }\end{array}$ & 1.19 \\
\hline $\begin{array}{l}\text { Country Risk (Political \& Regulatory) vs } \\
\text { Construction \& Operating Risk }\end{array}$ & 1.65 \\
\hline $\begin{array}{l}\text { Financial \& Revenue Risks vs } \\
\text { Promoting \& Procurement Risks }\end{array}$ & 2.62 \\
\hline $\begin{array}{l}\text { Financial \& Revenue Risks vs } \\
\text { Development Risk }\end{array}$ & 1.94 \\
\hline $\begin{array}{l}\text { Financial \& Revenue Risks vs } \\
\text { Construction \& Operating Risk }\end{array}$ & 2.19 \\
\hline $\begin{array}{l}\text { Promoting \& Procurement Risks vs } \\
\text { Development Risk }\end{array}$ & 0.60 \\
\hline $\begin{array}{l}\text { Promoting \& Procurement Risks vs } \\
\text { Construction \& Operating Risk }\end{array}$ & 0.56 \\
\hline $\begin{array}{l}\text { Development Risk vs Construction \& } \\
\text { Operating Risk } \\
\text { Category group weights }\end{array}$ & 0.83 \\
\hline Country Risk (Political \& Regulatory) & 0.234 \\
\hline Financial \& Revenue Risks & 0.311 \\
\hline Promoting \& Procurement Risks & 0.114 \\
\hline Development Risk & 0.170 \\
\hline Construction \& Operating Risk & 0.171 \\
\hline
\end{tabular}

\subsection{Attribute weights}

The twenty-eight Risk Factors were classified and placed within their respective Risk Category: six in the Financial \& Revenue Risks category, six within the Country Risks category, six within the Promoting \& Procurement Risks category, six under the Construction \& Operating Risks category and four attributes under the Development Risks category.

The relative importance to the participants of each attribute within each category and also the local attribute weights are presented in Table 3. Considering the local weights of attributes within their categories, it is apparent that "Changes in general legislation" will affect the project and the regulations in the "Country Risks" category. The "failure to raise the necessary finance" will affect the "Financial \& Revenue" risks category. "Lack of integrity during the tendering process" will affect the "Promoting \& Procurement Risks" category. "Changes in Design" during the construction phase will affect the "Development Risk" category. These are the most significant decision factors, which will have the maximum impact on the project risk, and therefore should be given a very high priority by the decision-maker.

The group weights of the Risk Factors were calculated by a similar method to that used for the Risk Category group weights, in order to find the contribution of each Risk Factor to its risk Category. From the results in Table 4 , it can be seen that the categories with the highest weights are as follows. "Changes in General Legislation Affecting the Project" in the "Country Risks" category, an "Failure to Raise Finance" in the "Financial \& Revenue" risks category, a "Lack of Integrity in the Tendering Process" in the "Promoting \& Procurement Risks" category, "Use of Technology" in the "Development Risk" category and "Inappropriate Operating Methods" in the "Construction \& Operating Risk" category. These weights are: $0.261,0.248,0.305,0.408$ and 0.242 respectively, within their Risk Categories. The weights of the attributes within each Risk Category, sum to unity.

Afterwards, the similarities and differences between individual weights were checked and the contributions of individual Risk Factors to the project risk were calculated. In order to do this, it was necessary to determine the individual relative weight of each Risk Factor towards the total project risk (composite weight " $W_{i}$ "). The composite weight of an attribute is equal to the local weight of that attribute " $W_{i}$ " multiplied by its local category weight " $W_{c}$ ":

$$
W_{i}=W^{1 *} W_{\mathrm{c}} .
$$

The sum of the composite weights of the attributes must equal unity, so:

$$
\Sigma W_{i}=1 \text {. }
$$

The composite weights of the twenty-eight Risk Factors were calculated from Eqn (2) for each contribution, displayed in Table 5 .

The average composite weight of each Risk Factor to within \pm standard deviation is given in Figure 3. These results show that the "use of technology", "unavailability of power supply" and the "Government's failure to provide permits", have the highest weights of $0.0707,0.065$ and 0.0636 , respectively, with the minimum standard deviation. However, a "lack of experience", "error in operation" and "maintenance cost estimates", as well as "lack of commitment to concession contracts" attributes, have the minimum weights of $0.0514,0.0500$ and 0.0464 , respectively.

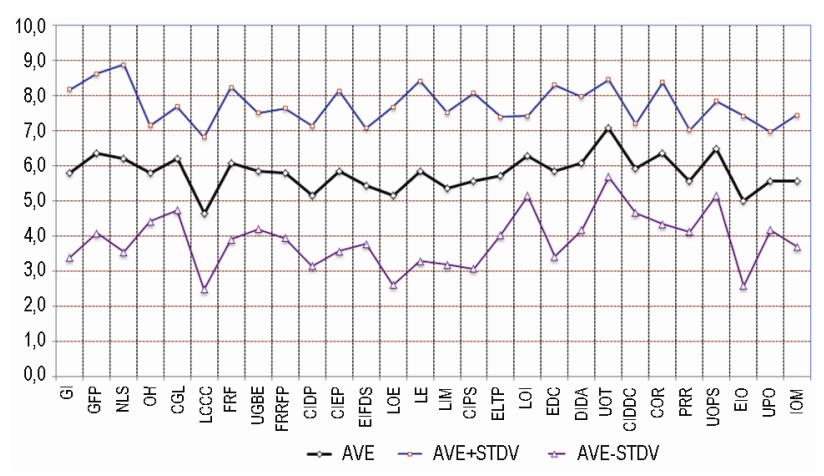

Fig. 3. Average EM composite attribute weights with its boundaries of \pm standard deviation 
Table 3. Risk decision factors: local attributes weights

\begin{tabular}{|c|c|c|c|c|c|c|c|c|c|c|c|c|c|c|}
\hline & $\mathrm{R} 1$ & $\mathrm{R} 2$ & R3 & $\mathrm{R} 4$ & R5 & R6 & R7 & $\mathrm{R} 8$ & R9 & $\mathrm{R} 10$ & R11 & $\mathrm{R} 12$ & $\mathrm{R} 13$ & $\mathrm{R} 14$ \\
\hline \multicolumn{15}{|c|}{ Country Risk (Political \& Regulatory) } \\
\hline GI & 0.453 & 0.029 & 0.037 & 0.274 & 0.124 & 0.026 & 0.431 & 0.042 & 0.484 & 0.027 & 0.1 & 0.152 & 0.056 & 0.096 \\
\hline GFP & 0.024 & 0.093 & 0.059 & 0.061 & 0.347 & 0.196 & 0.033 & 0.059 & 0.056 & 0.088 & 0.378 & 0.056 & 0.107 & 0.057 \\
\hline NLS & 0.078 & 0.347 & 0.171 & 0.334 & 0.189 & 0.086 & 0.135 & 0.096 & 0.216 & 0.416 & 0.162 & 0.431 & 0.134 & 0.039 \\
\hline $\mathrm{OH}$ & 0.116 & 0.03 & 0.193 & 0.028 & 0.224 & 0.102 & 0.153 & 0.175 & 0.028 & 0.089 & 0.211 & 0.037 & 0.261 & 0.478 \\
\hline CGL & 0.262 & 0.244 & 0.159 & 0.281 & 0.07 & 0.187 & 0.194 & 0.376 & 0.187 & 0.314 & 0.099 & 0.278 & 0.258 & 0.128 \\
\hline $\mathrm{LCCC}$ & 0.067 & 0.278 & 0.382 & 0.026 & 0.45 & 0.202 & 0.053 & 0.252 & 0.03 & 0.066 & 0.049 & 0.048 & 0.184 & 0.202 \\
\hline \multicolumn{15}{|c|}{ Financial \& Revenue Risks } \\
\hline FRF & 0.478 & 0.056 & 0.24 & 0.282 & 0.294 & 0.044 & 0.327 & 0.041 & 0.196 & 0.186 & 0.28 & 0.307 & 0.452 & 0.564 \\
\hline UGBE & 0.092 & 0.386 & 0.206 & 0.256 & 0.037 & 0.073 & 0.186 & 0.079 & 0.216 & 0.033 & 0.024 & 0.093 & 0.03 & 0.03 \\
\hline FRRFP & 0.115 & 0.3 & 0.084 & 0.184 & 0.302 & 0.077 & 0.164 & 0.128 & 0.215 & 0.062 & 0.279 & 0.096 & 0.73 & 0.202 \\
\hline CIDP & 0.154 & 0.059 & 0.206 & 0.175 & 0.202 & 0.309 & 0.234 & 0.902 & 0.15 & 0.1 & 0.217 & 0.43 & 0.248 & 0.044 \\
\hline CIEP & 0.08 & 0.099 & 0.152 & 0.026 & 0.12 & 0.32 & 0.047 & 0.124 & 1.217 & 0.353 & 0.105 & 0.044 & 0.118 & 0.6 \\
\hline EIFDS & 0.086 & 0.1 & 0.111 & 0.078 & 0.045 & 0.177 & 0.041 & 0.226 & 1.075 & 0.265 & 0.095 & 0.058 & 0.078 & 0.1 \\
\hline \multicolumn{15}{|c|}{ Promoting \& Procurement Risks } \\
\hline LOE & 0.030 & 0.074 & 0.026 & 0.040 & 0.029 & 0.066 & 0.026 & 0.058 & 0.028 & 0.050 & 0.196 & 0.084 & 0.025 & 0.113 \\
\hline LE & 0.099 & 0.162 & 0.041 & 0.202 & 0.083 & 0.039 & 0.040 & 0.115 & 0.037 & 0.028 & 0.028 & 0.028 & 0.215 & 0.286 \\
\hline LIM & 0.113 & 0.200 & 0.078 & 0.112 & 0.119 & 0.127 & 0.057 & 0.088 & 0.083 & 0.079 & 0.037 & 0.066 & 0.106 & 0.045 \\
\hline CIPS & 0.153 & 0.156 & 0.206 & 0.431 & 0.221 & 0.225 & 0.237 & 0.168 & 0.135 & 0.216 & 0.097 & 0.078 & 0.115 & 0.284 \\
\hline ELTP & 0.117 & 0.210 & 0.367 & 0.094 & 0.313 & 0.306 & 0.226 & 0.266 & 0.272 & 0.274 & 0.256 & 0.367 & 0.122 & 0.239 \\
\hline LOI & 0.487 & 0.197 & 0.281 & 0.121 & 0.235 & 0.237 & 0.414 & 0.035 & 0.445 & 0.353 & 0.387 & 0.375 & 0.418 & 0.034 \\
\hline \multicolumn{15}{|c|}{ Development Risks } \\
\hline EDC & 0.046 & 0.06 & 0.08 & 0.333 & 0.076 & 0.09 & 0.065 & 0.096 & 0.312 & 0.042 & 0.062 & 0.06 & 0.167 & 0.658 \\
\hline DIDA & 0.065 & 0.493 & 0.095 & 0.06 & 0.083 & 0.138 & 0.076 & 0.169 & 0.045 & 0.581 & 0.057 & 0.064 & 0.193 & 0.083 \\
\hline UOT & 0.368 & 0.181 & 0.413 & 0.274 & 0.481 & 0.502 & 0.401 & 0.368 & 0.378 & 0.218 & 0.44 & 0.497 & 0.047 & 0.048 \\
\hline CIDDC & 0.521 & 0.261 & 0.413 & 0.333 & 0.36 & 0.27 & 0.458 & 0.368 & 0.266 & 0.159 & 0.442 & 0.379 & 0.593 & 0.212 \\
\hline \multicolumn{15}{|c|}{ Construction \& Operating Risk } \\
\hline COR & 0.232 & 0.047 & 0.056 & 0.233 & 0.087 & 0.05 & 0.278 & 0.066 & 0.084 & 0.042 & 0.074 & 0.087 & 0.112 & 0.109 \\
\hline PRR & 0.387 & 0.16 & 0.122 & 0.047 & 0.105 & 0.056 & 0.327 & 0.088 & 0.089 & 0.069 & 0.105 & 0.192 & 0.204 & 0.028 \\
\hline UOPS & 0.033 & 0.08 & 0.058 & 0.152 & 0.315 & 0.176 & 0.032 & 0.153 & 0.241 & 0.07 & 0.309 & 0.137 & 0.066 & 0.422 \\
\hline EIO & 0.209 & 0.117 & 0.243 & 0.03 & 0.168 & 0.116 & 0.157 & 0.203 & 0.271 & 0.135 & 0.161 & 0.171 & 0.285 & 0.23 \\
\hline UPO & 0.061 & 0.11 & 0.37 & 0.208 & 0.144 & 0.287 & 0.062 & 0.297 & 0.104 & 0.342 & 0.199 & 0.137 & 0.074 & 0.143 \\
\hline IOM & 0.078 & 0.485 & 0.15 & 0.33 & 0.181 & 0.307 & 0.144 & 0.194 & 0.205 & 0.342 & 0.153 & 0.276 & 0.26 & 0.069 \\
\hline
\end{tabular}

Note: $\mathrm{GI}=$ government instability; GFP = government failure to provide permits; NLS = non-existence of the legal and regulatory system; $\mathrm{OH}=$ outbreak of hostilities (wars, riots, and terrorism); $\mathrm{CGL}=$ changes in general legislation affect the project; LCCC $=$ lack of commitment to concession contracts; FRF $=$ Failure to raise finance; UGBE $=$ Undeveloped general business environment; FRRFP = Failure to receive revenues from principal (end user); CIDP = Changes in demand of the facility over concession period; CIEP $=$ Change in economic policies; EIFDS $=$ Error in forecasting demands for service; $\mathrm{LOE}=\mathrm{Lack}$ of experience; LE = Lack of expertise; LIM = Lack of independent management; CIPS = Changes in project specifications; ELTP $=$ Expensive and long tendering process; LOI = Lack of integrity on the tendering process; EDC = Excessive development cost; DIDA = Delays in design approval; UOT $=$ Use of technology; CIDDC $=$ Changes in design during construction; $\mathrm{COR}=$ Cost-overrun risks; PRR $=$ Performance related risk; UOPS $=$ Unavailability of power supply; EIO = Error in operation and maintenance cost estimate; UPO = Unavailability and quality of personnel to operate the facility; IOM = Inappropriate operating methods.

The respondents recommended that the BOT project participants should pay particular attention to the "Country", "Construction \& Operating" and "Financial" Risk categories. However, they also suggested that they need to consider all the other model risks, because their weights are relatively close.

The relative importance of an attribute to the total project risk is given by its group composite weight. This can be found by multiplying the Risk Factor weights (Table 4) by the corresponding group Risk Category weights (Table 2).
For example, to find the group composite weight of the attribute "Government Instability", the group weight of this attribute must be multiplied by the group weight of the "Country" Risk category. Therefore, we find that the group composite weight of this attribute is $0.126 \times 0.234=0.02945$. Table 6 shows the group composite weights of attributes towards the project risk. The highest weights of $7.7 \%, 6.9 \%, 6.1 \%, 4.1 \%$ and $3.5 \%$ were allotted to "failure to raise finance", "use of technology", "changes in general legislation" affecting the project, "inappropriate operating methods" and "lack of integrity on the $t$ endering process" attributes in the 
Table 4. Group weights for comparison of attributes within their categories

\begin{tabular}{|c|c|}
\hline Attribute & $\begin{array}{c}\text { Group } \\
\text { Weight }\end{array}$ \\
\hline \multicolumn{2}{|l|}{ Country Risk (Political \& Regulatory) } \\
\hline Government instability & 0.126 \\
\hline Government failure to provide permits & 0.101 \\
\hline Non-existence of the legal and regulatory system & 0.242 \\
\hline $\begin{array}{l}\text { Outbreak of hostilities (wars, riots, and terro- } \\
\text { rism) }\end{array}$ & 0.142 \\
\hline $\begin{array}{l}\text { Changes in general legislation affecting the } \\
\text { project }\end{array}$ & 0.261 \\
\hline Lack of commitment to concession contracts & 0.128 \\
\hline \multicolumn{2}{|l|}{ Financial \& Revenue Risks } \\
\hline Failure to raise finance & 0.248 \\
\hline Undeveloped general business environment & 0.103 \\
\hline $\begin{array}{l}\text { Failure to receive revenues from principal end } \\
\text { user }\end{array}$ & 0.165 \\
\hline $\begin{array}{l}\text { Changes in demand of the facility over conces- } \\
\text { sion period }\end{array}$ & 0.222 \\
\hline Change in economic policies & 0.130 \\
\hline Error in forecasting demands for service & 0.132 \\
\hline \multicolumn{2}{|l|}{ Promoting \& Procurement Risks } \\
\hline Lack of experience & 0.056 \\
\hline Lack of expertise & 0.079 \\
\hline Lack of independent management & 0.088 \\
\hline Changes in project specifications & 0.207 \\
\hline Expensive and long tendering process & 0.264 \\
\hline Lack of integrity in the tendering process & 0.305 \\
\hline \multicolumn{2}{|l|}{ Development Risks } \\
\hline Excessive development cost & 0.113 \\
\hline Delays in design approval & 0.115 \\
\hline Use of technology & 0.408 \\
\hline Changes in design during construction & 0.364 \\
\hline \multicolumn{2}{|l|}{ Construction \& Operating Risk } \\
\hline Cost-overrun risks & 0.106 \\
\hline Performance related risk & 0.130 \\
\hline Unavailability of power supply & 0.150 \\
\hline Error in operation and maintenance cost estimate & 0.184 \\
\hline $\begin{array}{l}\text { Unavailability and quality of personnel to oper- } \\
\text { ate the facility }\end{array}$ & 0.188 \\
\hline Inappropriate operating methods & 0.242 \\
\hline
\end{tabular}

"Financial", "Development", "Country", "Construction \& Operating", and "Promoting \& Procurement" categories, respectively.

In Figure 4, the individual range of each attribute weight, shown in the form of a column, can be seen. For each attribute, the lower part of the column represents the minimum importance weights, which were assigned by respondents, while the top of the column indicates the maximum importance weights.

The darker line in the middle indicates the group composite weight of the attribute, while the dark regions, which can be seen above and below the line of group composite weights, indicate the standard deviation of the individual Group composite Risk Factors with individual composite weights, where half of the standard deviation is above and the other half is below the line. A table, which includes the data displayed in Figure 4, can be found in the Appendix. A close look at these figures

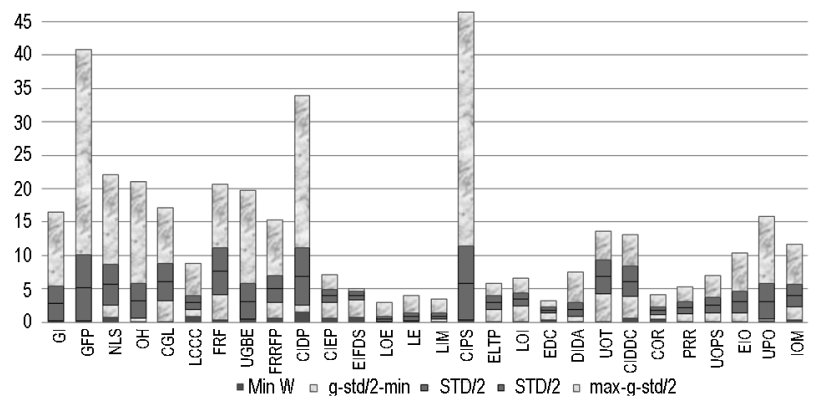

Fig. 4. Group composite attribute weights with range of individual composite weights

indicates that three attributes have quite a large range between their maximum and minimum importance weights. "Changes in the project specifications" attribute will have the maximum range of weight difference, with reference to the different replies from the respondents, (the minimum weight was given by R13 'government consultant' and the maximum weight was given by R6 'private consultant'). Three attributes have quite a small range (i.e. the difference in weight) with the 'lack of experience' attribute having the smallest, due to the fact that respondents have approximately the same view regarding the risk weight for the project team experience.

\subsection{Attributes worth scores and the framework validation approach}

It was Dias and Ioannou (1995b) who stated that, due to multi-attribute decision models being essentially subjective in nature, it is difficult to use external criteria to assess the validity of evaluation models objectively. For this reason, previous researchers have used indirect approaches, such as convergent validation, predictive validation and axiomatic validation. Convergent validation involves comparing the results obtained by a multiattribute decision framework with holistic evaluations made by the decision maker. For this approach, several alternative projects are defined and then evaluations, based on the framework and on the decision maker's judgments, are compared from how they rate and/or rank the alternatives. If there is a good correlation between the decomposed framework and the holistic evaluation, then it can be verified that the framework meets the decision maker's holistic evaluation. A convergent validation approach was used to validate the risk multi-attribute decision framework. An existing BOT projects, the Sulaibiya Waste Water Plant in Kuwait, was described and presented to the respondents, who were then asked to evaluate the performance of the framework attributes in the three project profiles on a scale of $1-9$ and then to rate them holistically using a scale of $0-10$. One of the most prominent of BOT projects in Kuwait was the Sulaibiya Waste Water Plant and it was chosen for this reason. In this case, unlike the Dias and Ioannou (1995b) approach, the performance value of $p 1$ is kept at zero in the other alternative $(\mathrm{P} 2=100)$ approaches. The reason for this assumption was because experts considered that all of the selected risk factors were significant and that their impact on the outcome of the project risk would be measurable. 
The $p 2=100$ approach involved keeping the performance point $\mathrm{P} 2$ at 100 points in order to increase the range of performance satisfaction. The "worth" of each project profile was calculated using different decomposed evaluation approaches (that due to Dias and Ioannou, $\mathrm{P} 2=100$ ). To achieve this, the following approaches were used.

The decomposed evaluation approach $(\mathrm{P} 2=100)$ was used to calculate the "worth" score for each project profile in order to establish the best approach to obtaining the holistic evaluation.

\section{Dias and Ioannou (1995b) approach}

For each model attribute, the worth score $V_{i}\left(x_{i}\right)$ was calculated by means of the value curves, considering points $\mathrm{P} 1$ and $\mathrm{P} 2$ as the performance extremes. However, when the attribute's performance $\mathrm{P} \leq \mathrm{P} 1$, the attribute's worth will receive a zero score, but if $\mathrm{P}<\mathrm{P} 2$, a 100 score will result. In order to ascertain the attributes" "worth", the value curve, based on the modified value curve of Dias and Ioannou, was used.

\section{$P 2=100$ approach}

For this approach, the P1 value is always equal to zero, based on the logical assumption that all of the framework decision factors (attributes) are important and will have some impact on the project risk. Their performance level P must therefore be considered in the evaluation (even for very small performance values where $\mathrm{P} \leq$ P1), whilst the P2 value is always equal to 9 (the extremely desirable point on the performance scale). The value curve will therefore extend from the origin to the extreme point of extremely desirable.

\section{Risk framework decision factors evaluation results}

The attributes contribution to the project risk can now be found for each approach by multiplying their worth scores by their composite weights and the total project value (index) will be the result of the decomposed evaluations according to Eqn (1). The individual holistic evaluations and the decomposed evaluation by Eigenvalue Method (EM) of the P2 = 100 approach for each project profile provided are shown in Table 7.

Table 5. Local composite weights of the attribute towards the project risk $(\times 10 \mathrm{E}-2)$

\begin{tabular}{|c|c|c|c|c|c|c|c|c|c|c|c|c|c|c|}
\hline & R1 & $\mathrm{R} 2$ & R3 & $\mathrm{R} 4$ & R5 & R6 & R7 & $\mathrm{R} 8$ & R9 & $\mathrm{R} 10$ & R11 & $\mathrm{R} 12$ & R13 & $\mathrm{R} 14$ \\
\hline \multicolumn{15}{|c|}{ Country Risk (Political \& Regulatory) } \\
\hline GI & 13.7 & 0.1 & 0.2 & 16.6 & 3.1 & 0.2 & 7.5 & 0.2 & 2.64 & 1.4 & 2.4 & 0.43 & 0.7 & 4.2 \\
\hline GFP & 0.7 & 0.3 & 0.3 & 38 & 8.6 & 1.2 & 0.6 & 0.3 & 3.1 & 4.7 & 9.2 & 1.6 & 1.4 & 2.5 \\
\hline NLS & 2.3 & 1.7 & 0.8 & 2.5 & 4.7 & 1.7 & 2.3 & 0.6 & 11.8 & 22.1 & 3.9 & 11.2 & 1.8 & 1.7 \\
\hline $\mathrm{OH}$ & 3.5 & 0.2 & 0.9 & 1.7 & 5.6 & 0.6 & 2.7 & 1 & 1.5 & 4.7 & 5.1 & 1 & 3.5 & 21.1 \\
\hline CGL & 7.9 & 1.2 & 0.7 & 17.2 & 1.7 & 1.1 & 3.4 & 0.2 & 10.3 & 16.7 & 2.4 & 7.9 & 3.4 & 5.7 \\
\hline $\mathrm{LCCC}$ & 2 & 1.4 & 1.8 & 1.6 & 1.1 & 1.2 & 0.9 & 1.5 & 1.7 & 3.5 & 1.2 & 1.3 & 2.5 & 8.9 \\
\hline \multicolumn{15}{|c|}{ Financial \& Revenue Risks } \\
\hline FRF & 18.7 & 2.9 & 2.1 & 7.4 & 5 & 0.4 & 14.9 & 0.5 & 4.3 & 3.8 & 5.8 & 11 & 17.2 & 20.7 \\
\hline UGBE & 3.6 & 19.8 & 1.8 & 6.7 & 0.6 & 0.7 & 8.5 & 1 & 6.3 & 0.7 & 0.5 & 3.3 & 1.1 & 1.1 \\
\hline FRRFP & 4.3 & 15.4 & 0.8 & 4.8 & 0.51 & 0.7 & 7.5 & 1.5 & 6.3 & 1.3 & 5.8 & 2.5 & 2.8 & 7.4 \\
\hline CIDP & 6 & 3 & 1.8 & 4.6 & 34 & 2.8 & 10.7 & 4.8 & 4.4 & 2 & 4.5 & 15.4 & 9.5 & 1.6 \\
\hline CIEP & 3.1 & 5.1 & 1.4 & 0.7 & 2 & 2.9 & 2.1 & 1.5 & 6.4 & 7.2 & 2.2 & 1.6 & 4.5 & 2.2 \\
\hline EIFDS & 3.4 & 5.1 & 1 & 2 & 0.8 & 1.6 & 1.9 & 2.7 & 1.7 & 4.5 & 2 & 2.1 & 3 & 3.7 \\
\hline \multicolumn{15}{|c|}{ Promoting \& Procurement Risks } \\
\hline LOE & 0.2 & 1.3 & 0.3 & 0.2 & 0.5 & 1.3 & 0.3 & 1.3 & 0.1 & 0.3 & 3 & 0.5 & 0.1 & 0.6 \\
\hline LE & 0.7 & 2.8 & 0.5 & 0.8 & 1.5 & 0.7 & 0.5 & 2.5 & 2 & 0.2 & 4 & 0.2 & 0.8 & 1.6 \\
\hline LIM & 0.8 & 3.5 & 0.9 & 0.5 & 2.1 & 2.4 & 0.7 & 1.9 & 0.4 & 0.4 & 0.6 & 0.4 & 0.4 & 0.2 \\
\hline CIPS & 1 & 2.7 & 2.4 & 1.8 & 3.9 & 43 & 3.1 & 3.7 & 0.7 & 1.2 & 1.5 & 0.5 & 0.4 & 1.6 \\
\hline ELTP & 0.8 & 3.7 & 4.2 & 0.4 & 5.5 & 5.9 & 3 & 5.8 & 1.4 & 1.5 & 4 & 0.2 & 0.34 & 1.3 \\
\hline LOI & 3.3 & 3.5 & 3.2 & 0.5 & 4.1 & 4.6 & 5.5 & 6.7 & 2.2 & 2 & 6 & 2.2 & 1.5 & 0.2 \\
\hline \multicolumn{15}{|c|}{ Development Risks } \\
\hline EDC & 0.8 & 1 & 2.6 & 1.4 & 2.2 & 2.5 & 0.6 & 1.3 & 1.3 & 0.4 & 1.7 & 1.4 & 3.3 & 2.3 \\
\hline DIDA & 1.2 & 7.6 & 3 & 0.2 & 2.4 & 3.8 & 0.7 & 2.4 & 0.2 & 5.3 & 1.5 & 1.5 & 3.8 & 0.3 \\
\hline UOT & 6.7 & 2.8 & 13.2 & 1.1 & 0.13 & 13.7 & 3.5 & 5.1 & 1.6 & 2 & 11.19 & 11.9 & 0.9 & 0.2 \\
\hline CIDDC & 9.5 & 4 & 13.2 & 1.4 & 10.4 & 7.4 & 4 & 5.1 & 1.1 & 1.4 & 11.9 & 9 & 11.6 & 0.7 \\
\hline \multicolumn{15}{|c|}{ Construction \& Operating Risk } \\
\hline COR & 1.3 & 0.5 & 2.4 & 1 & 1 & 1.9 & 4.2 & 3 & 0.6 & 0.5 & 0.9 & 0.5 & 2.8 & 1.1 \\
\hline PRR & 2.2 & 1.7 & 5.3 & 0.2 & 1.2 & 2.5 & 5 & 4.1 & 0.6 & 0.8 & 1.3 & 1.2 & 5.2 & 0.3 \\
\hline UOPS & 0.2 & 0.9 & 2.5 & 0.7 & 3.7 & 6.7 & 0.5 & 7.1 & 1.6 & 0.8 & 3.9 & 0.8 & 1.7 & 4.3 \\
\hline EIO & 1.2 & 1.3 & 10.4 & 0.1 & 2 & 4.5 & 2.4 & 9.4 & 1.8 & 1.6 & 2 & 1 & 7.2 & 2.3 \\
\hline UPO & 0.3 & 1.2 & 15.9 & 0.9 & 1.7 & 11 & 0.9 & 13.7 & 0.7 & 4.1 & 2.5 & 0.8 & 1.9 & 1.5 \\
\hline IOM & 0.4 & 5.5 & 6.5 & 1.4 & 2.1 & 11.7 & 2.2 & 9 & 1.4 & 4.1 & 1.9 & 1.7 & 6.6 & 0.7 \\
\hline
\end{tabular}


Table 6. Attribute group composite weight

\begin{tabular}{lc}
\hline Attribute & $\begin{array}{c}\text { Group Composite } \\
\text { Weight }(\times 10 \mathrm{E}-2)\end{array}$ \\
\hline $\begin{array}{l}\text { Country Risk (Political \& Regulatory) } \\
\text { Government instability }\end{array}$ & 2.90 \\
Government failure to provide permits & 2.40 \\
Non-existence of the legal and regulato- & 5.70 \\
ry system & \\
Outbreak of hostilities (wars, riots, and & 3.30 \\
terrorism) & \\
Changes in general legislation affecting & 6.10 \\
the project & \\
Lack of commitment to concession & 3.00 \\
contracts & \\
Financial \& Revenue Risks & 7.70 \\
Failure to raise finance & 3.20 \\
Undeveloped general business envi- & \\
ronment & 5.10 \\
Failure to receive revenues from princi- \\
pal (end user)
\end{tabular}

The average results of the project profiles decomposed evaluations for each of the respondents were calculated for the P2 $=100$ approach and plotted against the average holistic evaluation and the results are given in Figure 3. The differences between the P2 approach and the holistic evaluation are compared from observations, the P2 = 100 approach curve is found to be very close to the holistic curve, which means that it captures the holistic approach. The group results of the holistic and decomposed evaluations for each project profile were calculated by taking the averages of the individual evaluations and the results are shown in Table 7. In order to validate the framework, the holistic and the decomposed evaluation were compared by Pearson's product moment corre- lation coefficient (r). The correlation process compared the individual holistic evaluations and decomposed evaluations, which were obtained from the model. The results, as shown in Table 7, indicate that the framework correlates well with the holistic approach (the correlations range between 0.71 and 0.81 ).

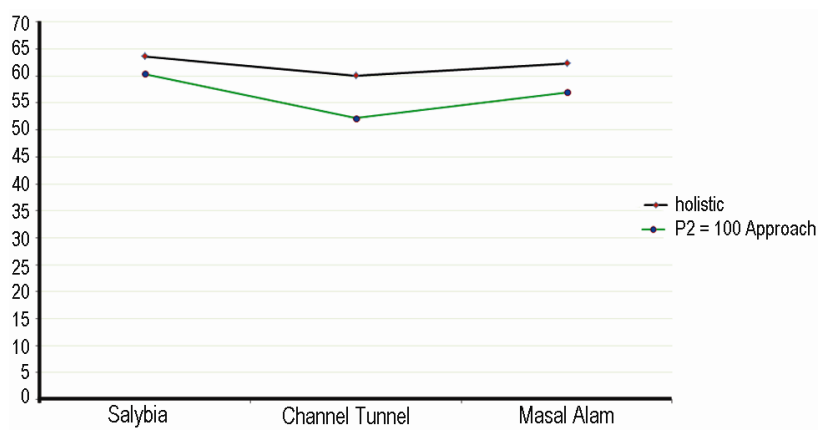

Fig. 5. Comparison between average holistic and decomposed evaluation approaches

\section{Using the risk framework in the project risk study}

The identified results and the participants' feedback were used to assess the current BOT Risk Management Framework and to advise concerning the amendments that need to be made to the Framework. Feedback from the participants in the field study indicated that many aspects of the proposed framework would be a helpful aid to decision-makers, in both the public and private sectors.

The main reason for the development of the risk framework was to help the decision-maker in evaluating the risk of their infrastructure project during the preliminary stages, before proceeding with the project. In this manner, both the private sector and the Government in Kuwait should have a fuller picture of the most important $\mathrm{BOT}$ risks that they will face when considering the initiation of BOT projects in Kuwait. Having a more informed "picture" will facilitate the process of risk management (risk allocation, mitigation) in the early stages of procurement of BOT Infrastructure projects.

Using the Risk Management Framework involves the assignment of the most important Risk Factor weights and their performance (quality) levels, developing Risk Factor value curves $(\mathrm{P} 2=100)$ and computing the project risk index. When the Risk Factor indexes, which form the total project risk index, have been determined, those Risk Factors that affect the total project risk, will be apparent and the decision-maker can then implement strategies to manage these risks and re-evaluate them, so that their effect on the project can be mitigated and/or minimized.

For example, considering the use of the $\mathrm{P} 2$ approach in the Sulaibiya Waste Water Treatment Plant Project, the resulting value indices for the twenty-eight risk Factors, as shown in Table 8 and Figure 6, indicate that the "Use of Technology" (UOT) Risk Factor is the highest weighted Risk Factor in the project with a value index of 3.30. Whereas, "Inappropriate Operating Methods" (IOM) Risk Factor is the second highest weighed Risk Factor with a value index of 3.0. "Unavailability and quality of personnel to operate the facility", had a 
weighed Risk Factor of 2.98 , closely followed by "Performance Related Risk" (PRR) with a weighed Risk Factor with a value index of 2.95. "Excessive Development Costs" has a weighed Risk Factor with a value index of 2.52. "Change in Project Specification" has a weighed Risk Factor with a value index of 2.52, "Error in Forecasting Demand for Service" has a weighed Risk Factor with a value index of 2.50 , and "Failure to receive revenues from principal (end user)" has a weighed Risk Factor with a value index of 2.50 . Therefore, the decisionmakers should pay more attention to the above Risk Factors than to the others, because their effect on project risk/viability is more critical and risk management techniques are required in order to mitigate and/or minimize their effect by allocating the risks to a party which is capable of handling them.

The most salient Risk Factors for the Sulaibiya Waster Water Plant will be considered and the "Use of Technology" Risk Factor indicating that there was public concern that the water (collected from sewage) was not being treated correctly, nor thoroughly enough, to be acceptable as drinking water. The second part to this was that the equipment used in the filtering and cleaning processes was not up to date and not operated correctly.
Excessively sophisticated technology may not be practicable in some BOT projects, not only increasing to the initial cost of the project but increasing operation, maintenance and repair costs. Suitable technology needs to be updated during the operating time of the plant and be fit for purpose during, and after, the handover at the end of the concession period.

Second Risk Factor was "Inappropriate Operating Methods" at 3.00, relating to the unavailability of trained personnel, i.e. whoever was operating the plant, would they do it right? And this posed major concerns regarding safety of the water. It can be seen that these first tow Risk Factors are closely linked. This risk factor is due to a shortage of highly skilled productive workers, i.e. Scientists \& Engineers and of those working in the company, due to cultural values and belief, there is a perception that there is a lack of work ethic. It can be overcome by having experienced and reliable management personnel. Good management personnel as well as experienced operating personnel are needed to operate the plant. The senior management of the plant makes the operating decision policy and arranges for the training, maintenance and inspection regime of operation system of the plant.

Table 7. Local composite weights of the attribute towards the project risk $(\times 10 \mathrm{E}-2)$

\begin{tabular}{|c|c|c|c|c|c|c|c|c|c|c|c|c|c|c|}
\hline & $\mathrm{R} 1$ & $\mathrm{R} 2$ & R3 & $\mathrm{R} 4$ & R5 & R6 & R7 & $\mathrm{R} 8$ & R9 & $\mathrm{R} 10$ & R11 & $\mathrm{R} 12$ & $\mathrm{R} 13$ & $\mathrm{R} 14$ \\
\hline \multicolumn{15}{|c|}{ Country Risk (Political \& Regulatory) } \\
\hline GI & 13.7 & 0.1 & 0.2 & 16.6 & 3.1 & 0.2 & 7.5 & 0.2 & 2.64 & 1.4 & 2.4 & 0.43 & 0.7 & 4.2 \\
\hline GFP & 0.7 & 0.3 & 0.3 & 38 & 8.6 & 1.2 & 0.6 & 0.3 & 3.1 & 4.7 & 9.2 & 1.6 & 1.4 & 2.5 \\
\hline NLS & 2.3 & 1.7 & 0.8 & 2.5 & 4.7 & 1.7 & 2.3 & 0.6 & 11.8 & 22.1 & 3.9 & 11.2 & 1.8 & 1.7 \\
\hline $\mathrm{OH}$ & 3.5 & 0.2 & 0.9 & 1.7 & 5.6 & 0.6 & 2.7 & 1 & 1.5 & 4.7 & 5.1 & 1 & 3.5 & 21.1 \\
\hline CGL & 7.9 & 1.2 & 0.7 & 17.2 & 1.7 & 1.1 & 3.4 & 0.2 & 10.3 & 16.7 & 2.4 & 7.9 & 3.4 & 5.7 \\
\hline LCCC & 2 & 1.4 & 1.8 & 1.6 & 1.1 & 1.2 & 0.9 & 1.5 & 1.7 & 3.5 & 1.2 & 1.3 & 2.5 & 8.9 \\
\hline \multicolumn{15}{|c|}{ Financial \& Revenue Risks } \\
\hline FRF & 18.7 & 2.9 & 2.1 & 7.4 & 5 & 0.4 & 14.9 & 0.5 & 4.3 & 3.8 & 5.8 & 11 & 17.2 & 20.7 \\
\hline UGBE & 3.6 & 19.8 & 1.8 & 6.7 & 0.6 & 0.7 & 8.5 & 1 & 6.3 & 0.7 & 0.5 & 3.3 & 1.1 & 1.1 \\
\hline FRRFP & 4.3 & 15.4 & 0.8 & 4.8 & 0.51 & 0.7 & 7.5 & 1.5 & 6.3 & 1.3 & 5.8 & 2.5 & 2.8 & 7.4 \\
\hline CIDP & 6 & 3 & 1.8 & 4.6 & 34 & 2.8 & 10.7 & 4.8 & 4.4 & 2 & 4.5 & 15.4 & 9.5 & 1.6 \\
\hline CIEP & 3.1 & 5.1 & 1.4 & 0.7 & 2 & 2.9 & 2.1 & 1.5 & 6.4 & 7.2 & 2.2 & 1.6 & 4.5 & 2.2 \\
\hline EIFDS & 3.4 & 5.1 & 1 & 2 & 0.8 & 1.6 & 1.9 & 2.7 & 1.7 & 4.5 & 2 & 2.1 & 3 & 3.7 \\
\hline \multicolumn{15}{|c|}{ Promoting \& Procurement Risks } \\
\hline LOE & 0.2 & 1.3 & 0.3 & 0.2 & 0.5 & 1.3 & 0.3 & 1.3 & 0.1 & 0.3 & 3 & 0.5 & 0.1 & 0.6 \\
\hline LE & 0.7 & 2.8 & 0.5 & 0.8 & 1.5 & 0.7 & 0.5 & 2.5 & 2 & 0.2 & 4 & 0.2 & 0.8 & 1.6 \\
\hline LIM & 0.8 & 3.5 & 0.9 & 0.5 & 2.1 & 2.4 & 0.7 & 1.9 & 0.4 & 0.4 & 0.6 & 0.4 & 0.4 & 0.2 \\
\hline CIPS & 1 & 2.7 & 2.4 & 1.8 & 3.9 & 43 & 3.1 & 3.7 & 0.7 & 1.2 & 1.5 & 0.5 & 0.4 & 1.6 \\
\hline ELTP & 0.8 & 3.7 & 4.2 & 0.4 & 5.5 & 5.9 & 3 & 5.8 & 1.4 & 1.5 & 4 & 0.2 & 0.34 & 1.3 \\
\hline LOI & 3.3 & 3.5 & 3.2 & 0.5 & 4.1 & 4.6 & 5.5 & 6.7 & 2.2 & 2 & 6 & 2.2 & 1.5 & 0.2 \\
\hline \multicolumn{15}{|c|}{ Development Risks } \\
\hline EDC & 0.8 & 1 & 2.6 & 1.4 & 2.2 & 2.5 & 0.6 & 1.3 & 1.3 & 0.4 & 1.7 & 1.4 & 3.3 & 2.3 \\
\hline DIDA & 1.2 & 7.6 & 3 & 0.2 & 2.4 & 3.8 & 0.7 & 2.4 & 0.2 & 5.3 & 1.5 & 1.5 & 3.8 & 0.3 \\
\hline UOT & 6.7 & 2.8 & 13.2 & 1.1 & 0.139 & 13.7 & 3.5 & 5.1 & 1.6 & 2 & 11.19 & 11.9 & 0.9 & 0.2 \\
\hline CIDDC & 9.5 & 4 & 13.2 & 1.4 & 10.4 & 7.4 & 4 & 5.1 & 1.1 & 1.4 & 11.9 & 9 & 11.6 & 0.7 \\
\hline \multicolumn{15}{|c|}{ Construction \& Operating Risk } \\
\hline COR & 1.3 & 0.5 & 2.4 & 1 & 1 & 1.9 & 4.2 & 3 & 0.6 & 0.5 & 0.9 & 0.5 & 2.8 & 1.1 \\
\hline PRR & 2.2 & 1.7 & 5.3 & 0.2 & 1.2 & 2.5 & 5 & 4.1 & 0.6 & 0.8 & 1.3 & 1.2 & 5.2 & 0.3 \\
\hline UOPS & 0.2 & 0.9 & 2.5 & 0.7 & 3.7 & 6.7 & 0.5 & 7.1 & 1.6 & 0.8 & 3.9 & 0.8 & 1.7 & 4.3 \\
\hline EIO & 1.2 & 1.3 & 10.4 & 0.1 & 2 & 4.5 & 2.4 & 9.4 & 1.8 & 1.6 & 2 & 1 & 7.2 & 2.3 \\
\hline UPO & 0.3 & 1.2 & 15.9 & 0.9 & 1.7 & 11 & 0.9 & 13.7 & 0.7 & 4.1 & 2.5 & 0.8 & 1.9 & 1.5 \\
\hline IOM & 0.4 & 5.5 & 6.5 & 1.4 & 2.1 & 11.7 & 2.2 & 9 & 1.4 & 4.1 & 1.9 & 1.7 & 6.6 & 0.7 \\
\hline
\end{tabular}


Table 8. Risk index value for the Sulaibiya Wastewater Treatment plant project in Kuwait

\begin{tabular}{|c|c|c|}
\hline Risk Attribute & & $\begin{array}{c}\mathrm{P} 2=100 \\
\text { Value } \\
\text { Index }\end{array}$ \\
\hline Government instability & GI & 2.03 \\
\hline Government failure to provide permits & GFP & 1.85 \\
\hline $\begin{array}{l}\text { Non-existence of the legal and regulato- } \\
\text { ry system }\end{array}$ & NLS & 2.46 \\
\hline $\begin{array}{l}\text { Outbreak of hostilities (wars, riots, and } \\
\text { terrorism) }\end{array}$ & $\mathrm{OH}$ & 1.93 \\
\hline $\begin{array}{l}\text { Changes in general legislation affecting } \\
\text { the project }\end{array}$ & CGL & 2.20 \\
\hline $\begin{array}{l}\text { Lack of commitment to concession } \\
\text { contracts }\end{array}$ & $\mathrm{LCCC}$ & 1.85 \\
\hline Failure to raise finance & FRF & 1.87 \\
\hline $\begin{array}{l}\text { Undeveloped general business environ- } \\
\text { ment }\end{array}$ & UGBE & 2.01 \\
\hline $\begin{array}{l}\text { Failure to receive revenues from princi- } \\
\text { pal (end user) }\end{array}$ & FRRFP & 2.50 \\
\hline $\begin{array}{l}\text { Changes in demand for the facility over } \\
\text { concession period }\end{array}$ & CIDP & 1.41 \\
\hline Change in economic policies & CIEP & 2.49 \\
\hline Error in forecasting demands for service & EIFDS & 2.50 \\
\hline Lack of experience & LOE & 2.48 \\
\hline Lack of expertise & LE & 2.43 \\
\hline Lack of independent management & LIM & 2.10 \\
\hline Changes in project specifications & CIPS & 2.52 \\
\hline Expensive and long tendering process & ELTP & 1.96 \\
\hline $\begin{array}{l}\text { Lack of integrity in the (tendering pro- } \\
\text { cess) }\end{array}$ & LOI & 1.65 \\
\hline Excessive development costs & EDC & 2.52 \\
\hline Delays in design approval & DIDA & 2.46 \\
\hline Use of technology & UOT & 3.30 \\
\hline Changes in design during construction & CIDDC & 2.06 \\
\hline Cost-overrun risks & COR & 1.96 \\
\hline Performance related risk & PRR & 2.95 \\
\hline Unavailability of power supply & UOPS & 2.06 \\
\hline $\begin{array}{l}\text { Error in operation and maintenance cost } \\
\text { estimate }\end{array}$ & EIO & 2.11 \\
\hline $\begin{array}{l}\text { Unavailability and quality of personnel } \\
\text { to operate the facility }\end{array}$ & UPO & 2.98 \\
\hline Inappropriate operating methods & IOM & 3.00 \\
\hline
\end{tabular}

In the third place is the "Unavailability and quality of personnel to operate the facility" Risk Factor can be initially addressed by the private sector who are required by the BOT contract to provide the personnel and expertise to run and operate the facility to a good standard including any technical documentation. BOT infrastructure project contracts in future in Kuwait must include provisions that the private sector provides education and training to Kuwaitis in order ensure that the operation of the plant is maintained to a good standard. This becomes crucial when approaching the end of the concession period to allow a smooth transfer and operation of the plant.

The fourth Risk Factor was "Performance Risk Factor" indicating that there is a perception that the monitoring of the BOT infrastructure facility during the concession period is not carried out correctly by the Kuwaiti government. Proper monitoring of performance during the concession period is essential, not only for the success of the project and its continued operation after the concession period, but to ensure that the consumer is getting "value for money". There may also be a concern during construction whereby, sub-contractors do not complete their part of the project on time or to the required standard or specification. Performance incentives could be introduced to encourage the contractor to complete their part on time and to specification.

The fifth Risk Factor of "Excessive Development Cost" indicates that some private investors may be unenthusiastic about bidding for a BOT project due to high development costs which they may never recover. Decision-makers should pay more attention to the above Risk Factors than to the others, because their effect on project risk/viability is more critical and risk management techniques are required in order to mitigate and/or minimize their effect by allocating the risks to a party which is capable of handling them.

Sixth Risk Factor was the "Change in Project Specification", a Risk Factor taken very seriously by the private sector but not so seriously by the public sector (as Figure 4 demonstrates where the "group composite weights" of the importance of this Risk Factor were completely opposite to each other depending on the respondent place of work, i.e. Private company and very important; or Public Sector and not so important).

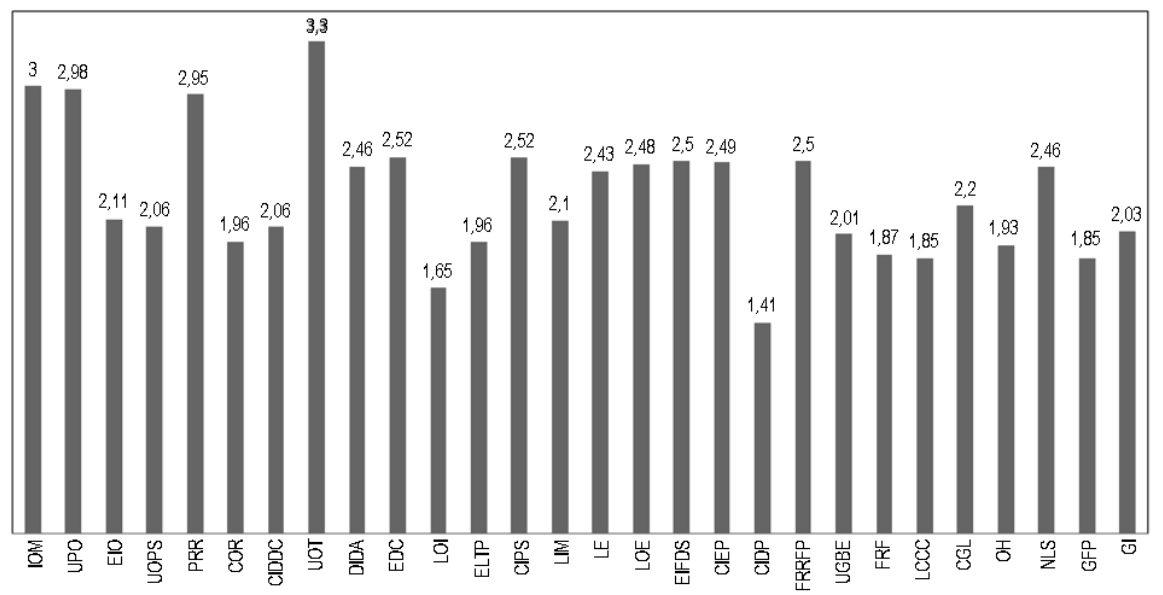

Fig. 6. Risk index value for the Sulaibiya Wastewater Treatment Plant project in Kuwait 
Seventh Risk Factor was "Failure to receive revenues from principal (end user)". For services such as electricity and water, government officials do not collect/ask for payment. Therefore, ordinary people just do not pay their bills. This has become the "norm" in Kuwait and as a result, all moneys due are cancelled after 5 years because people cannot be expected to pay the full accumulated amount in one go. This extends to the private sector as well, where private companies do not pay any utility bills either. This has become standard practice and is a part of Kuwaiti culture as the government rarely enforces existing laws and does not prosecute any people/companies. Also, recently, people are advised by some MP's not to pay any utility bills because the MP's are making promises that the bills will be cancelled and paid by the government as a form of vote chasing. The prevailing public attitude is: "As Kuwait is such a rich country, then the government can afford to pay". There have been various efforts by past governments to make people pay their utility bills, including discounts, and even amnesties to make a fresh start, but nothing has worked so far. The present government has recently taken a tougher stance in that: if a citizen of Kuwait has an outstanding utility bill then they are not allowed to leave the country without paying the utility bill first, and the government has opened offices in Airports and border crossings to enable citizens to pay their utility bills before being allowed to leave the country.

The eight Risk Factor, but not the last, is "Error in Forecasting Demand for Service" and could be due to changes in demand of the product due to economic downturns or competition. In the case of failure to receive sufficient revenues from the end user, the Kuwaiti government should allow the private company to revise their pricing structure, and even provide loans and/or grants whenever the revenues drop below certain amounts agreed in the contract. In the case of competition, the Kuwaiti government is in a unique position at the outset of the procurement process to protect the project from competition, i.e. there is a guarantee that a competing plant will be built during the lifetime of the existing project. Changing economic policies by the Kuwaiti government is another method of guaranteeing agreed revenue earnings, i.e. the Kuwaiti government takes a lower percentage of the profit thereby guaranteeing the private company's profit margin. Error in forecasting long term demands for service(s) may prompt the Kuwaiti government to change the length of the concession period of the BOT project with compensation being paid to the private company and the time of the handover brought forward.

The index value listing of the Risk Factors, determined by the Kuwaiti respondents, may have been due to their perception of, and attitude to, risk based on experience gained mainly in Kuwait. Furthermore, the questionnaire was answered after all of the respective BOT infrastructure projects had been completed and "hindsight" may have played a significant part in their evaluation of the risks; "Experience is something one gains a second after it is needed". Although the Risk Management Framework was constructed after the completion of the case study, it does still provide a valuable insight into the potential risk areas of the case study with respect to Kuwait.

\section{Conclusions}

This study has identified twenty eight major risk factors affecting BOT infrastructure projects in Kuwait and these have then been classified under their main relative categories, "Financial \& Revenue Risks", "Country Risks", "Construction \& Operating Risks", "Development Risks" and "Promotion \& Procurement Risks", in order to determine their inter-relationships and their effect on the project. The project risk factors were evaluated by means of a Risk Management Framework. The importance of the decision factors were weighted by means of 'Expert Choice 11.5', utilizing the Analytical Hierarchy Process (AHP), technique adopted by Saaty (1980). The results indicated that the "Financial \& Revenue" category was the most important $(31.10 \%)$, followed by "Country" Risks (23.40\%), and then "Construction \& Operation" $(17.10 \%)$, next in importance are "Development" $(17.00 \%)$ and finally "Promoting \& Procurement" $(11.40 \%)$ categories. From these results, it can be deduced that the project viability is mainly dependent on the management of the financial and commercial Risk Factors. It is important that, during the project feasibility study stage, the crucial sensitive Risk Factors are taken into account and evaluated. In an effort to determine the contributions of the decision factors to the project risk index, the P2 = 100 approach was applied to a case study project (The Sulaibiya Wastewater Treatment Plant in Kuwait). The outcomes were correlated to the direct holistic evaluation of the project profile and the indications were that the outcomes of the $\mathrm{P} 2=100$ approach were very close to the holistic evaluation (the Pearson coefficient lies between 0.77 indicating a good correlation).

In this paper, the Authors present the following contributions to risk analysis of BOT infrastructure projects:

-A list of the most important qualitative decision factors involving risk in BOT infrastructure projects, which have been carefully identified, selected and then screened by a group of experts within Kuwait was provided;

- This study makes a contribution to work in the field of BOT Infrastructure projects in the context of Kuwait, as it is one of the very few studies on Kuwait that have been conducted in this area. Although the BOT method has been successfully used in many countries, Kuwait has had little experience in using private finance for its infrastructure projects, as it has certain characteristics requiring special attention;

- The study will be of help to private sector companies who have insufficient knowledge concerning the business environment within the country and it will also benefit the public sector, which has limited experience of partnership;

-A new framework "P2 = 100" approach, provides an in-depth analysis of the qualitative, (linguistic), decision factors which have previously been evaluated in an arbitrary way. Since the decision-makers within the Kuwaiti Government and the private sector usual- 
ly consider only the project quantitative, (numeric), decision factors, this could change their method of thinking and help them re-evaluate their attitude and perception of risks effecting BOT projects;

-An appropriate decision-support tool, which should help the decision-maker to determine those risk decision factors which would prove most effective in minimizing if not eliminating some project risks, and we also put forward some strategies to increase the performance of these factors is proposed.

With regard to further work, researchers need to track these critical factors during the life-time of many BOT infrastructure projects. Specific software solutions that can deal with the complex nature of such infrastructural projects should be developed. The suggested output for such software should include indexes for different options, supported by graphs and tables which illustrate the inter-relationships between the factors which can be easily applied by all parties involved in BOT infrastructure projects.

\section{References}

Ahmed, F. M. S.; Miroslaw, J. S.; Ismail, B. 2007. BOT viability models for large scale infrastructure projects, Journal of Construction Engineering and Management ASCE 133(1): 50-63. http://dx.doi.org/10.1061/(ASCE)07339364(2007)133:1(50)

Askar, M.; Gab-Allah, A. 2002. Problems facing parties involved in build, operate, and transfer projects in Egypt, Journal of Management in Engineering 18(4): 173-178. http://dx.doi.org/10.1061/(ASCE)0742597X(2002)18:4(173)

Baloi, D.; Price, A. D. F. 2003. Modeling global risk factors affecting construction cost performance, International Journal of Project Management 21(4): 261-269. http://dx.doi.org/10.1016/S0263-7863(02)00017-0

Cheung, E.; Chan, A. P. C.; Kajewski, S. 2010.The public sector's perspective on procuring public works projects comparing the views of practitioners in Hong Kong and Australia, Journal of Civil Engineering and Management 16(1): 19-32. http://dx.doi.org/10.3846/jcem.2010.02

Dey, P. K.; Ogulana, S. O. 2004. Selection and application of risk management tools and techniques for build-operatetransfer projects, Industrial Management and Data Systems 104(4): 334-346.

http://dx.doi.org/10.1108/02635570410530748

Dey, P. K.; Ogunlana, S. O.; Takehiko, N. 2002. Risk management in build-operate-transfer projects, International Journal of Risk Assessment and Management 3(2/3/4): 269-291.

Delmon, J. 2000. BOO/BOT projects: a commercial and contractual guide. London: Sweet \& Maxwell Limited, 1: 40-62.

Dias, A. Jr.; Ioannou, G. Ph. 1995a. Debt capacity and optimal capital structure for privately financed infrastructure projects, Journal of Construction Engineering and Management, ASCE Dec, 404-414.

http://dx.doi.org/10.1061/(ASCE)07339364(1995)121:4(404)

Dias, A. Jr.; Ioannou, G. Ph. 1995b. Desirability model for the development of privately promoted infrastructure projects, UMCEE Report No.95-09, Vol. 1, University of Michigan, USA.

Ebrahimnejad, S.; Mousavi, S. M.; Seyrafianpour, H. 2010. Risk identification and assessment for build-operate- transfer projects: a fuzzy multi attribute decision making model, Expert Systems with Applications International Journal 37: 575-586.

http://dx.doi.org/10.1016/j.eswa.2009.05.037

Esq, L. F. 1996. Introduction to B.O.T., in Proc., Conf. on International Contracts of B.O.T. and Their Amicable Solutions, Vol. 1.

Flanagan, R.; Norman, N. 1993. Risk management and construction. London: Blackwell Scientific Publications. 208 p.

Ghosh, S.; Jintanapakanont, J. 2004. Identifying and assessing the critical risk factors in an underground rail project in Thailand: a factor analysis approach, International Journal of Project Management 22(8): 632-642.

http://dx.doi.org/10.1016/j.ijproman.2004.05.004

Grimsey, D.; Lewis, K. K. 2004. Public-Private Partnerships. Cheltman, UK: Edward Elgar.

http://dx.doi.org/10.4337/9781845423438

Gunn, S. 2005. Consideration of pre-contract risks in international PFI projects. Risk Management Considerations in Construction Projects. The University of Salford, Manchester, Salford Centre for Research and Innovation (SCRI).

Gupta, M. C.; Narasimham S. V. 1998. Discussion of CSFs in competitive tendering and negotiation model for BOT projects, Journal of Construction Engineering and Management, ASCE, Sept./Oct. $430 \mathrm{p}$.

Huang, Y. L. 1995. Project and policy analysis of buildoperate-transfer infrastructure development: $\mathrm{PhD}$ thesis. UMI Company, Michigan, 15-23.

Kim, G. 2010. Risk performance indexes and measurement systems for mega construction projects, Journal of Civil Engineering and Management 1(4): 586-594. http://dx.doi.org/10.3846/jcem.2010.65

Klein, M.; So, J.; Shin, B. 1996. Transaction costs in private infrastructure projects - are they too high? Public Policy of Private Sector, The World Bank, Washington, DC.

Kumaraswamy, M. M.; Morris, D. A. 2002. Build-operatetransfer-type procurement in Asian mega projects, Journal of Construction Engineering and Management 128(2): 93-102. http://dx.doi.org/10.1061/(ASCE)07339364(2002)128:2(93)

Levy, S. M. 1996. Build, operate, transfer paving the way for tomorrow's infrastructure. Toronto, Frank Mercede and Sons, Inc. Stamford, CT. 411 p.

Li, B.; Akintoye, A.; Edwards, P. J.; Hardcastle, C. 2005. The allocation of risk in PPP/PFI construction projects in the UK, International Journal of Project Management 23(1): 25-35. http://dx.doi.org/10.1016/j.ijproman.2004.04.006

Liddle, B. T. 1997. Privatization decision and civil engineering projects, Journal of Management in Engineering 13(3): 73-78. http://dx.doi.org/10.1061/(ASCE)0742597X(1997)13:3(73)

Loosemore, M. 2007. Risk allocation in the private provision of public infrastructure, International Journal of Project Management 25(1): 66-76.

http://dx.doi.org/10.1016/j.ijproman.2006.06.005

Loosemore, M.; Raftery, J.; Reilly, C.; Higgon, D. 2006. Risk management in projects. London: Taylor \& Francis. 260 p.

Miller, G. A. 1956. The magical number seven, plus or minus two: some limits on our capacity for processing information, Psychological Review 63(2): 81-97. http://dx.doi.org/10.1037/h0043158

Nassar, G. 1996. What is B.O.T. in Proc., Conf. on International Contracts of B.O.T. and Their Amicable Solutions, Vol. 1. 
National Council for Public-Private Partnerships, USA 2009. How PPPs work-Public-private partnerships defined [online], [cited 26 August 2009]. Available from Internet: http://www.ncppp.org/howpart/index.shtml

Ozdoganm, I. D.; Birgonul, M. T. 2000. A decision support framework for project sponsors in the planning stage of build-operate-transfer (BOT) projects, Journal of Construction Management and Economics 18(3): 343-353. http://dx.doi.org/10.1080/014461900370708

Ranasinghe, M. 1999. Private sector participation in infrastructure projects: a methodology to analyze viability of BOT, Journal of Construction Management and Economics 17(5): 613-623.

http://dx.doi.org/10.1080/014461999371222

Raz, T.; Michael, E. 2001. Use and benefits of tools for project risk management, International Journal of Project Management 19(1): 9-17. http://dx.doi.org/10.1016/S0263-7863(99)00036-8

Regan, M.; Smith, J.; Love, P. 2009. Public-private partnerships: what does the future hold, in Proc., RICS Construction and Building Research Conf. (COBRA), Royal Institution of Chartered Surveyors, London, 462-474.

Saaty, T. L. 1980. The analytical hierarchy process. USA: McGraw-Hill, Inc. 287 p.

Senturk, H. A.; Yazici, G.; Kaplanoglu, S. B. 2004. Case study: Izmit domestic and industrial water supply build-operatetransfer project, Journal of Construction Engineering and Management 130(3): 449-454.

http://dx.doi.org/10.1061/(ASCE)07339364(2004)130:3(449)

Shen, L. Y.; Bao, H. J.; Wu, Y. Z.; Lu, W. S. 2007. Using bargaining-game theory for negotiating concession period for BOT-type project, Journal of Construction Engineering and Management, ASCE 133(5): 385-392.

http://dx.doi.org/10.1061/(ASCE)07339364(2007)133:5(385)

Shen, L. Y.; Lee, K. H.; Zhang, Z. 1996. Application of BOT system for infrastructure projects in China, Journal of Construction Engineering and Management 122(4): 319-323. http://dx.doi.org/10.1061/(ASCE)07339364(1996)122:4(319)

Shen, L. Y.; Li, H.; Li, Q. M. 2002. Alternative concession model for build operate transfer contract project, Journal of Construction Engineering and Management, ASCE 128(4): 326-330. http://dx.doi.org/10.1061/(ASCE)07339364(2002)128:4(326)

Shen, L. Y.; Wu, Y. Z. 2005. Risk concession model for build operate transfer contract projects, Journal of Construction Engineering and Management, ASCE 131(2): 211-220. http://dx.doi.org/10.1061/(ASCE)07339364(2005)131:2(211)

Songer, A. D.; Diekmann, J.; Pecsok, R. S. 1997. Risk analysis for revenue dependent infrastructure projects, Construc- tion Management and Economics 15(4): 377-382.

http://dx.doi.org/10.1080/014461997372935

Tiong, R. L. K. 1990. Comparative study of BOT projects, Journal of Management in Engineering, ASCE, January, 6: 107-122.

Tiong, R. L. K. 1995a. Risks and guarantees in BOT tender, Journal of Construction Engineering and Management, ASCE, June, 183-188. http://dx.doi.org/10.1061/(ASCE)07339364(1995)121:2(183)

Tiong, R. L. K. 1995b. Competitive advantage of equity of BOT tender, Journal of Construction Engineering and Management, ASCE, Sept., 282-289.

http://dx.doi.org/10.1061/(ASCE)07339364(1995)121:3(282)

Tiong, R. L. K. 1995c. Impact of financial package versus technical solution in BOT tenders, Journal of Construction Engineering and Management, ASCE, Sept, 304-311. http://dx.doi.org/10.1061/(ASCE)07339364(1995)121:3(304)

Tiong, R. L. K. 1996. CSFs in competitive tendering and negotiation model for BOT projects, Journal of Construction Engineering and Management, ASCE, Sept, 202-211.

Tiong, R. L. K.; Alum, J. 1997. Final negotiation in competitive BOT tender, Journal of Construction Engineering and Management, ASCE 6-10.

http://dx.doi.org/10.1061/(ASCE)07339364(1997)123:1(6)

Tiong, R. L. K.; Yeo, K. M.; McCarthy, S. C. 1992. Critical success factors in winning BOT contracts, Journal of Construction Engineering and Management, ASCE, June, 217-228. http://dx.doi.org/10.1061/(ASCE)07339364(1992)118:2(217)

United Nations Industrial Development Organisation UNIDO 1996. Guidelines for Infrastructure Development through Build-Operate-Transfer (BOT) Projects, Vienna.

Walker, C.; Smith, A. 1995. Privatized infrastructure the build operate transfer approach. London: Thomas Telford Services Ltd. http://dx.doi.org/10.1680/pitba.20535

Wilburn, W. K.; Thomas, J. R. 1994. Build-operate-transfer. An emerging trend in project financing, Construction Business View, May/June.

World Bank. 1994. World development report: infrastructure for development. Rep. No. 13184, Washington, D.C.

Zayed, T. M.; Chang, L. M. 2002. Prototype model for buildoperate-transfer risk assessment, Journal of Management Engineering 18(1): 7-16. http://dx.doi.org/10.1061/(ASCE)0742$597 X(2002) 18: 1(7)$

Zavadskas, E. K; Turskis, Z.; Tamošaitienè, J. 2010. Risk assessment of construction projects, Journal of Civil Engineering and Management 16(1): 33-46. http://dx.doi.org/10.3846/jcem.2010.03

Khalid Fahad AL-AZEMI. He is a member of the Kuwait Society of Engineers, and a PhD Graduate of Wolfson School of Mechanical and Manufacturing Engineering, Loughborough University, UK, received his MSc in Engineering and Manufacturing Management from Coventry University, UK. His main research interest is risk management in buildoperate-transfer (BOT) infrastructure projects.

Ran BHAMRA. A Senior Lecturer in Engineering Management in the Wolfson School of Mechanical and Manufacturing Engineering at Loughborough University. He has over 15 years of manufacturing industry experience in manufacturing engineering and management. His main research interests include organisational strategy, resilience and sustainability.

Ahmed F. M. SALMAN. Assistant Professor of Construction Engineering and Management, BSc in Civil Engineering, from Zagazig University in Egypt in 1986, MSc in Construction Management from Zagazig University, Egypt in 1994, and $\mathrm{PhD}$ from, Zagazig University, Egypt, and Purdue University, USA "Joint Supervision grant". His main research interest areas are in construction project management, Build-Operate and Transfer (BOT), construction engineering modeling and decision making, and international construction contracting. 